\title{
Building an 18000 -year-long paleo-earthquake record from detailed deep-sea turbidite characterisation in Poverty Bay, New Zealand
}

\author{
H. Pouderoux ${ }^{1,2}$, G. Lamarche ${ }^{2}$, and J.-N. Proust ${ }^{1}$ \\ ${ }^{1}$ Géosciences-Rennes, Université de Rennes 1, UMR6118, Campus de Beaulieu, 35042, Rennes cedex, France \\ ${ }^{2}$ National Institute of Water and Atmospheric Research (NIWA) Ltd, Private Bag 14-901, Wellington, 6241, New Zealand \\ Correspondence to: H. Pouderoux (h.pouderoux@yahoo.fr), G. Lamarche (g.lamarche@niwa.co.nz), \\ J.-N. Proust (jean-noel.proust@univ-rennes1.fr)
}

Received: 20 October 2011 - Revised: 23 May 2012 - Accepted: 25 May 2012 - Published: 27 June 2012

\begin{abstract}
Two $\sim 20$ m-long sedimentary cores collected in two neighbouring mid-slope basins of the Paritu Turbidite System in Poverty Bay, east of New Zealand, show a high concentration of turbidites ( 5 to 6 turbidites per meter), interlaid with hemipelagites, tephras and a few debrites. Turbidites occur as both stacked and single, and exhibit a range of facies from muddy to sandy turbidites. The age of each turbidite is estimated using the statistical approach developed in the OxCal software from an exceptionally dense set of tephrochronology and radiocarbon ages $(\sim 1$ age per meter). The age, together with the facies and the petrophysical properties of the sediment (density, magnetic susceptibility and Pwave velocity), allows the correlation of turbidites across the continental slope (1400-2300 m water depth). We identify 73 synchronous turbidites, named basin events, across the two cores between $819 \pm 191$ and $17729 \pm 701 \mathrm{yr} \mathrm{BP}$. Compositional, foraminiferal and geochemical signatures of the turbidites are used to characterise the source area of the sediment, the origin of the turbidity currents, and their triggering mechanism. Sixty-seven basin events are interpreted as originated from slope failures on the upper continental slope in water depth ranging from 150 to $1200 \mathrm{~m}$. Their earthquake trigger is inferred from the heavily gullied morphology of the source area and the water depth at which slope failures originated. We derive an earthquake mean return time of $\sim 230 \mathrm{yr}$, with a $90 \%$ probability range from 10 to $570 \mathrm{yr}$. The earthquake chronology indicates cycles of progressive decrease of earthquake return times from $\sim 400 \mathrm{yr}$ to $\sim 150 \mathrm{yr}$ at 0 $7 \mathrm{kyr}, 8.2-13.5 \mathrm{kyr}, 14.7-18 \mathrm{kyr}$. The two $1.2 \mathrm{kyr}-l o n g$ intervals in between (7-8.2 kyr and 13.5-14.7 kyr) correspond to basin-wide reorganisations with anomalous turbidite deposition (finer deposits and/or non deposition) reflecting the
\end{abstract}

emplacement of two large mass transport deposits much more voluminous than the "classical" earthquake-triggered turbidites. Our results show that the progressive characterisation of a turbidite record from a single sedimentary system can provide a continuous paleo-earthquake history in regions of short historical record and incomplete onland paleoearthquake evidences. The systematic description of each turbidite enables us to infer the triggering mechanism.

\section{Introduction}

Earthquake records need to include a large number of events so that meaningful statistical analysis can be undertaken and used for seismic hazard assessments. For large earthquakes with return intervals of hundreds to thousands of years, this implies the building of earthquake chronologies going back several thousands of years. While this may be achievable in regions where human occupation extends over a few thousands of years, like in the Mediterranean Basin (e.g. Gràcia et al., 2010) and the Marmara Sea region (e.g. McHugh et al., 2006), this is not the case in Oceania where human settlements are more recent. Hence, the need to develop specific methodologies and protocols to investigate past earthquakes is critical for countries like New Zealand. There, less than $1000 \mathrm{yr}$ of human occupation and limited historical record covering only the last $\sim 170 \mathrm{yr}$ mean that evidence of past large earthquakes along the plate boundary is scarce. Although paleo-earthquakes have been identified, the data are incomplete reflecting the fragmented nature of the terrestrial record upon which the paleoseismic history is based (Berryman, 1993; Cochran et al., 2006; Goff and 
Dominey-Howes, 2009; Hayward et al., 2006; Wilson et al., 2006, 2007).

Submarine paleoseismology is a developing field of science that aims to characterise offshore earthquake sources and develop protocols and methodology to build earthquake histories from marine environments (Pantosti et al., 2011). This includes identifying and justifying the use of new paleo-earthquake proxies. Amongst those, gravity flow deposits and turbidites have been successfully used as paleoearthquake indicators in a number of environments including the Cascadia margin (Adams, 1990; Goldfinger et al., 2003, 2007), the northern San Andreas Fault (Goldfinger et al., 2008), the northern Ecuador Margin (Ratzov et al., 2010), the southwestern Iberian Margin (Gràcia et al., 2010), Haiti (McHugh et al., 2011) and Japan (Huh et al., 2004; Nakajima and Kinai, 2000; Noda et al., 2008). Turbidite paleoseismology is a method essentially based on the identification of synchronous turbidity currents from different sedimentary systems and the correlation with historical earthquakes. Many issues remain in using turbidites as paleo-earthquake proxy, in particular the need to identify the triggering mechanisms of the turbidites and extract the paleo-earthquake record from areas lacking significant historical records.

The Hikurangi Margin in New Zealand is an ideal location for turbidite paleoseismology studies. This is particularly valid in the Poverty Bay region (Fig. 1), where very high sediment delivery $\left(\sim 15 \mathrm{Mt} \mathrm{a}^{-1}\right.$; Hicks and Shankar, 2003; Hicks et al., 2004), high deposition on the continental shelf and slope ( $\sim 1 \mathrm{~cm} \mathrm{a}^{-1}$; Foster and Carter, 1997; Miller and Kuehl, 2010; Rose and Kuehl, 2010), a very large number of turbidites (3.7-6.7 turbidites $\mathrm{kyr}^{-1}$; Lewis and Pettinga, 2004; Pouderoux et al., 2012), presence of well-dated tephras to underpin chronologies (Lowe et al., 2008) and intense earthquake activity $\left(\sim 4 M_{\mathrm{w}} \geq 5\right.$ earthquakes per year since 1940 ; geonet.co.nz; Doser and Webb, 2003; Reyners and McGinty, 1999; Webb and Anderson, 1998) provide the right environment to apply and further develop such studies. Furthermore, onshore studies in the Hawke Bay-Poverty Bay region have provided a paleo-earthquake record to compare with over the last $9 \mathrm{ka}$ based on uplifted marine terraces (Wilson et al., 2006; 2007), subsidence episodes (Cochran et al., 2006; Hayward et al., 2006), and tsunamis coastal deposits (Cochran et al., 2006; Goff and Dominey-Howes, 2009).

This study aims to show that the turbidite record from a turbidite system fed by a single source region can be used as a paleo-earthquake proxy over a $18 \mathrm{ka}$ period, in order to define the age, frequency, source and impact of large and repetitive earthquakes. The objectives are to (1) provide a precise age of each turbidity currents that have flowed in the Paritu Turbidite System, demonstrated by the correlation of turbidites over the system, (2) define the source area and the origin of the turbidity currents, (3) establish the earthquake trigger of these slope failures, and (4) propose a chronology of earthquakes over an $18 \mathrm{ka}$ period.

\section{The northern Hikurangi Margin}

\subsection{Regional settings}

The Hikurangi Margin is a region of intense tectonic and seismic activity associated with the oblique subduction of the Pacific Plate beneath the eastern North Island (Fig. 1). The margin divides in southern and northern segments at $\sim 39^{\circ} 30^{\prime} \mathrm{S}$, in Hawke Bay. Along the northern segment, a 20-30 km-wide continental shelf, a steep sediment-starved inner trench wall, and the two large Poverty (Pedley et al., 2010) and Ruatoria (Collot et al., 1996; Collot et al., 2001; Lewis et al., 2004) morphological re-entrants together indicate large-scale tectonic erosion, but in presence of continuing high sediment accumulation.

The Poverty re-entrant covers an area of $\sim 1500 \mathrm{~km}^{2}$ of rough morphology characterised by gullies, ridges, troughs, channels and hummocks (Fig. 2a). The re-entrant is the result of successive continental slope failures since $\sim 1500 \mathrm{ka}$ (Pedley et al., 2010). It divides in two distinct morphological and sedimentary systems: the Poverty Canyon System to the south and the Paritu Turbidite System to the north (Orpin, 2004; Fig. 1). The present study focuses on the latter, which has characteristic morphological features(Fig. 2a): a heavily gullied upper slope at $150-1200 \mathrm{~m}$ water depth; the midslope east-west Paritu Trough at $1200-1500 \mathrm{~m}$ water depth; the margin-parallel North and South Paritu Ridges, which are separated by a NW-SE-trending Paritu Channel, that leads downslope into a NE-SW trending Lower Paritu Basin at $2300 \mathrm{~m}$ water depth (Orpin, 2004; Pedley et al., 2010). The Paritu Trough covers approximately $250 \mathrm{~km}^{2}$. Its hummocky seafloor corresponds to the Poverty Debris Avalanche (PDA; Fig. 2a; Orpin, 2004; Mountjoy and Micallef, 2012; Pedley et al., 2010). The PDA is composed of two mass transport deposits (U1 and U2), emplaced from massive slope failures of the upper slope that remobilised about $33 \pm 5 \mathrm{~km}^{3}$ of material. The emplacement of the PDA is older than $3410 \mathrm{yr} \mathrm{BP}$ (Orpin, 2004), and could be as old as $13.6 \mathrm{kyr}$ (Pouderoux et al., 2012).

At present, intense onland erosion results in the Waipaoa River delivering up to $15 \mathrm{Mt}$ of sediment per year onto the continental shelf and slope (Fig. 1; Hicks and Shankar, 2003). The drastic environmental changes due to human colonisation beginning about 500-700 years ago and after European settlement $170 \mathrm{yr}$ ago (McGlone et al., 1994; McGlone and Wilmshurst, 1999) increased by $\sim 660 \%$ the sediment delivery (Gomez et al., 2004, 2007; Kettner et al., 2007). Presently, the Waipaoa River may generate hyperpycnal flows once every $40 \mathrm{yr}$ (Hicks et al., 2004), whose deposits are rarely preserved in the sedimentary record of the shelf (Rose and Kuehl, 2010). Catastrophic climatic events such as the 1988 Cyclone Bola and subsequent flood, recorded on the inner shelf, differentiate from the hemipelagic background by their finer grain size and strong terrestrial carbon signatures (Brackley et al., 2010; Foster 


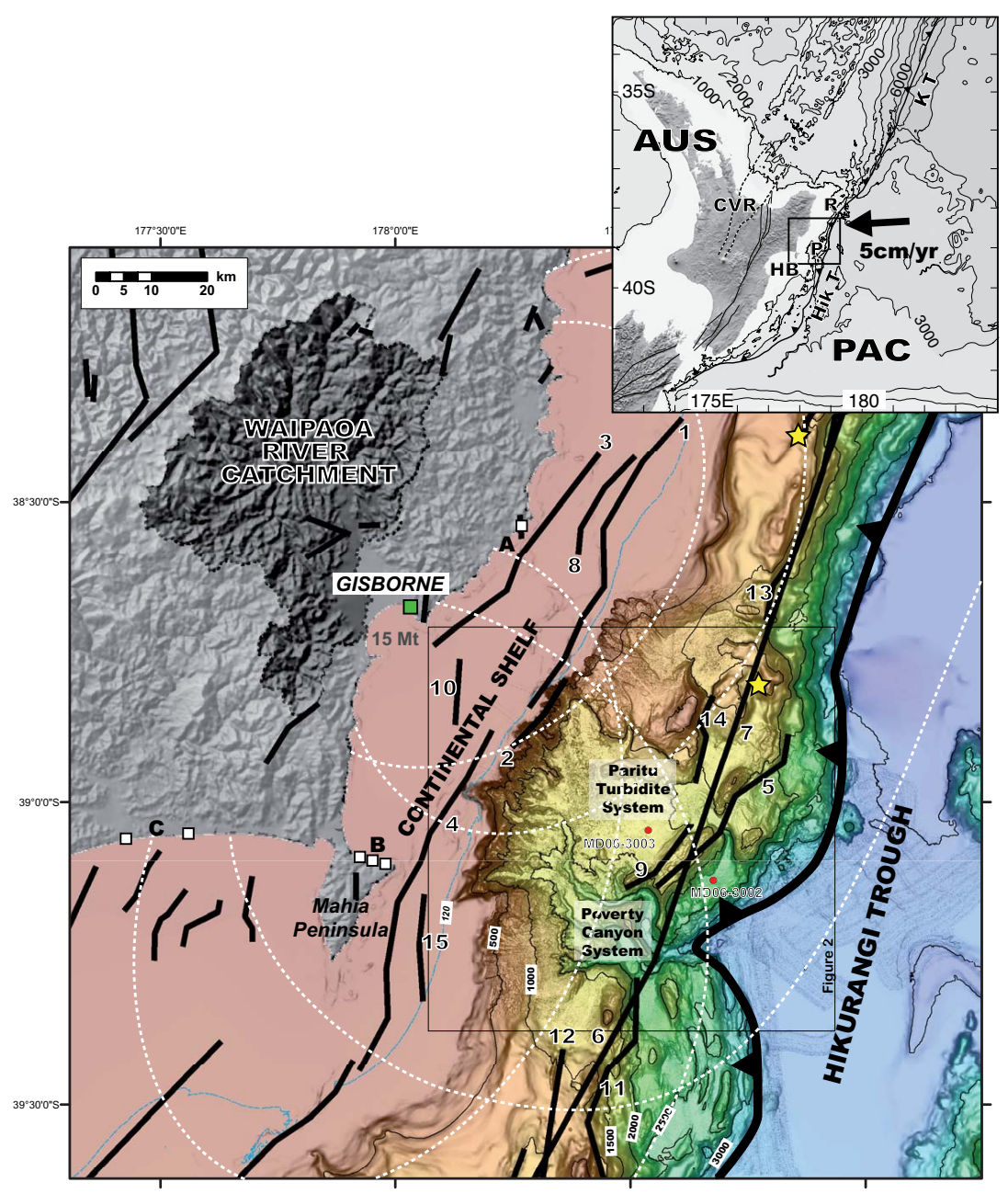

Fig. 1. Seafloor morphology of the Poverty Bay region, northern Hikurangi margin, with contours in meters below sea level. Yellow stars show the epicenters of the 1947 Poverty earthquakes $\left(M_{\mathrm{W}}=6.9\right.$ and 7.1) (Doser and Webb, 2003; Downes et al., 2000). Coastal paleoearthquakes evidences are shown with white squares: (A) uplifted terraces at Pakarae River mouth (Wilson et al., 2006, 2007), (B) uplifted terraces at Mahia Peninsula (Berryman, 1993) and (C) subsided swamps in northern Hawke Bay (Cochran et al., 2006). The seismogenic segments of Stirling et al. (2012) are indicated with bold black lines with numbers referring to Table 1. White dashed ellipses are isoseismal MMIs VIII from Litchfield et al. (2009) for five active faults including the two interface segments. Bold teeth line is Pac-Aus subduction plate boundary. Red dots are location of the two Marion Dufresne cores used in this study. Location of Fig. 2a is indicated. Insert: the PacificAustralia (PAC-AUS) subduction plate boundary (teeth line) along the Hikurangi - Kermadec margin that runs along the Hikurangi Trough (Hik T) and Kermadec Trench (KT); the rectangle indicates the location of the Poverty region; the arrow indicates the relative Pac-Aus plate motion from Beavan et al. (2002); CVR: Central Volcanic Region, HB: Hawke Bay, P: Poverty re-entrant, R: Ruatoria re-entrant; EC: East Cape.

and Carter, 1997). Pre-human time floods and earthquakes have been suggested in a 2400-yr record generated using shelf and lake sediments (Gomez et al., 2007).

The rhyolitic Central Volcanic Region (Fig. 1), $350 \mathrm{~km}$ west of the subduction margin, is a prolific source of welldated, geochemically distinct tephras that punctuate the stratigraphic record throughout the Quaternary (Lowe et al., 2008).

\subsection{Seismicity}

Historical and pre-historical seismic records indicate a high recurrence of moderate earthquakes $\left(M_{\mathrm{w}}>6.5\right)$ along the Hikurangi Margin (Anderson and Webb, 1994; Doser and Webb, 2003; Webb and Anderson, 1998). The $1931 M_{\mathrm{W}}=$ 7.8 Napier earthquake is the most damaging historical earthquake that has affected the study area.

Large prehistoric earthquakes $\left(M_{\mathrm{W}}>7\right)$ are inferred from uplifted coastal terraces and subsided swamps younger than 9 ka (Fig. 1; Berryman et al., 1993; Cochran et al., 2006; 

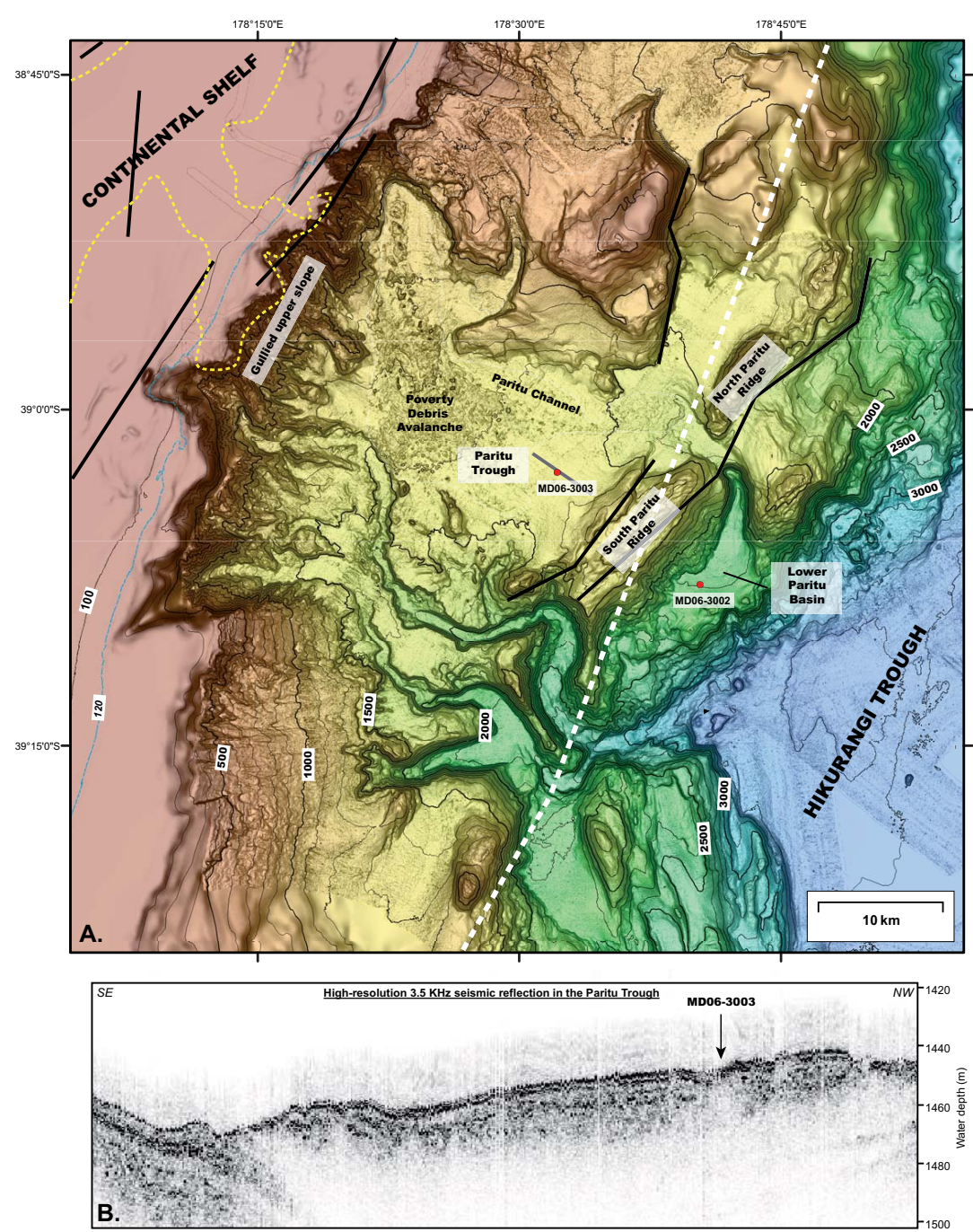

Fig. 2. (A) Bathymetric map of the Paritu mid-slope system. The extent of the Poverty Debris Avalanche in the Paritu Trough is indicated (Mountjoy and Micallef, 2012). Yellow dashed line represents the $10 \mathrm{~m}$ isobath of postglacial sedimentation after Orpin et al. (2006). White dashed line represents the Raukumara-Hikurangi and Hawke Bay-Hikurangi plate interface seismogenic segments; bold lines are active faults labelled in Fig. 1. (B) Example of high-resolution (3.5 KHz) seismic reflection centred on core MD06-3003.

Hayward et al., 2006; Wilson et al., 2006, 2007). The composite prehistoric earthquake record results in a mean return time of $\sim 800 \mathrm{yr}$. However, this record is likely to be incomplete since uplift and subsidence episodes are mainly driven by near-shore upper plate fault ruptures (Litchfield et al., 2010). Evidence of paleo-tsunamis for the last $6 \mathrm{kyr}$ is used as earthquake indicators when their deposits are consistent with local fault-generated earthquakes (Goff and DomineyHowes, 2009). The two 1947 Poverty earthquakes $\left(M_{\mathrm{W}}=\right.$ 6.9-7.1) generated tsunamis along $50-100 \mathrm{~km}$ of coastline but with no significant coastal uplift (Doser and Webb, 2003; Downes et al., 2000). Both have been interpreted as possibly originating from ruptures of narrow portions of the plate interface (Downes et al., 2000). The paleo-tsunami record provides a mean return time of $890 \mathrm{yr}$, but the record is possibly incomplete (Downes et al., 2000).

There are no plate interface ruptures unambiguously identified along the Hikurangi Margin. Great earthquakes $\left(M_{\mathrm{W}}>8\right)$ associated with a rupture of the plate interface have only been inferred from seismologic and geodetic modelling (Reyners, 1998; Reyners and McGinty, 1999; Wallace et al., 2009; Cochran et al., 2006; Stirling et al., 2012). The subduction interface model suggests two rupture segments for the northern Hikurangi Margin, the Raukumara segment to the north extending from the Mahia Peninsula to East Cape, and the Hawke Bay segment to the south, both capable of generating earthquake $M_{\mathrm{W}}>8$ (Litchfield et al., 2009; Wallace et al., 2009; Stirling et al., 2012) (Fig. 1; Table 1). 
Table 1. Characterization of the main active faults in the Poverty region.

\begin{tabular}{lrlrrrrr}
\hline & no. & Fault & $\begin{array}{r}\text { Length } \\
(\mathrm{km})\end{array}$ & $\begin{array}{r}\text { SR } \\
\left(\mathrm{mm} \mathrm{yr}^{-1}\right)\end{array}$ & $M_{\mathrm{W}}$ & $\begin{array}{r}\text { SED } \\
(\mathrm{m})\end{array}$ & $\begin{array}{r}\text { RI }) \\
\text { yr })\end{array}$ \\
\hline & 1 & Ariel Bank & 63 & 6.07 & 7.4 & 4.4 & 720 \\
& 2 & Ariel East & 16 & 1.56 & 6.6 & 1.1 & 720 \\
Faults used in this study & 3 & Gable End & 48 & 3.81 & 7.2 & 2.9 & 760 \\
& 4 & Lachlan 3 & 69 & 4.5 & 7.5 & 4.8 & 1070 \\
& 5 & Paritu Ridge & 39 & 2 & 6.9 & 2.7 & 1360 \\
& 6 & Hik. Hawke Bay & 200 & 8.8 & $8.2-8.4$ & $6.3-8.1$ & $1590-2050$ \\
& 7 & Hik. Raukumara & 200 & 10.8 & $8.2-8.4$ & $6.3-8.1$ & $1300-1670$ \\
\hline \multirow{5}{*}{ Other regional faults } & 8 & Ariel North & 22 & 0.93 & 6.8 & 1.5 & 1640 \\
& 9 & Paritu West & 17 & 1 & 6.5 & 1.2 & 1180 \\
& 10 & Poverty Bay & 12 & 2.33 & 6.5 & 0.8 & 360 \\
& 11 & Ritchie Ridge & 57 & 1.5 & 7.1 & 4 & 2650 \\
& 12 & Ritchie West 1 & 90 & 1 & 7.5 & 6.3 & 6270 \\
& 13 & Ruatoria South 1 & 72 & 1.5 & 7.3 & 5 & 3340 \\
& 14 & Tuaheni Ridge & 17 & 1 & 6.5 & 1.2 & 1180 \\
& 15 & Waihi South & 24 & 2 & 6.6 & 1 & 510 \\
\hline
\end{tabular}

Fault parameters are taken from the synthesis of Stirling et al. (2011) SR: Slip rate, $M_{\mathrm{W}}$ : maximum estimated moment magnitude, SED: Single event displacement, RI: Recurrence interval

\subsection{Sedimentation patterns}

Postglacial sedimentation in the Poverty region is mostly concentrated on the shelf, in distinct depocenters extending parallel to the coast line (Foster and Carter, 1997; Orpin et al., 2006; Gerber et al., 2010; Miller and Kuehl, 2010). The trapping efficiency of the shelf has reduced from $\sim 90 \%$ to $25 \%$ since human colonisation. Today, a significant amount of river sediments by-passes the shelf to reach the upper continental slope (Alexander et al., 2010; Gerber et al., 2010; Miller and Kuehl, 2010). Most Holocene sediments delivered by the Waipaoa River are trapped in mid-shelf basins (Gerber et al., 2010), or on the outer shelf (Fig. 2a), where postglacial thickness reaches $40 \mathrm{~m}$ (Orpin et al., 2006). Cross-shelf sediment pathways supplying this outer shelf depocenter were established early in the Holocene (Orpin et al., 2006).

On the continental slope, multibeam imagery identifies debris and avalanche deposits at the toe of the upper slope of the Paritu Turbidite System, arguing for a high slope instability (Orpin, 2004). This contrasts with the Late Holocene, during which the Poverty Canon System was largely inactive (Walsh et al., 2007). These activity patterns are confirmed by the morphology of the gullies, which shows mature (mostly inactive) gullies connecting to the Poverty Canyon System and intermediate to immature (mostly active) gullies connected to the Paritu Turbidite System (Fig. 2a; Mountjoy and Micallef, 2012).

In mid-slope basins, Mid-Late Holocene accumulation rate is estimated at $\sim 60 \mathrm{~cm} \mathrm{kyr}^{-1}$ (Orpin, 2004). Since $\sim 18 \mathrm{ka}$, postglacial sedimentation of the Paritu Trough and Lower Paritu Basin has been composed of airfall tephras, debrites, hemipelagites and turbidites, respectively associated with volcanic eruptions, debris flows, marine sedimentation and turbidity currents (Fig. 3; Orpin, 2004; Pouderoux et al., 2012). These authors show that (1) tephras consist of cm-thick, normally graded, pinkish silts composed exclusively of pumiceous ash. They have sharp basal contacts and are capped by a clayey bioturbated horizon; (2) debrites are cm-thick chaotic units of dark olive-grey silty clays containing sand to pebble size shell fragments. (3) Hemipelagites are cm-thick, light olive-grey silty clays with pervasive bioturbation; (4) turbidites are composed of $\mathrm{cm}$-thick, dark olive-grey to dark grey, normally graded units, with grain size ranging from 100 to $10 \mu \mathrm{m}$ upward. Basal sands are predominantly composed of quartz and volcaniclastic grains (pumiceous lapilli and glass shards. Turbidites have a sharp basal contact and a progressive and bioturbated upper boundary with hemipelagites; (5) the characterisation and differentiation of hemipelagites from turbidite tails are based on variations in composition, highlighted by colour changes, since grain size is very similar (Fig. 3); hemipelagites mostly contain volcaniclastic grains, usually pumiceous lapilli, whereas turbidite tails are essentially made up of quartz grains and the paleontological content (i.e. pelagic and benthic foraminifers) is low $(<10 \%)$ and is not a key parameter.

Furthermore, Pouderoux et al. (2012) show that turbidites make up $\sim 75 \%$ of the infilling with the remainder usually consisting of interbedded hemipelagites. In the Paritu Turbidite System, they are sub-divided into five distinct facies based on their grain size, internal structures, sand composition and foraminifer assemblage: muddy turbidites, silt laminae turbidites, silty turbidites, sandy turbidites and basal reverse-graded turbidites. The latter facies differs from the 


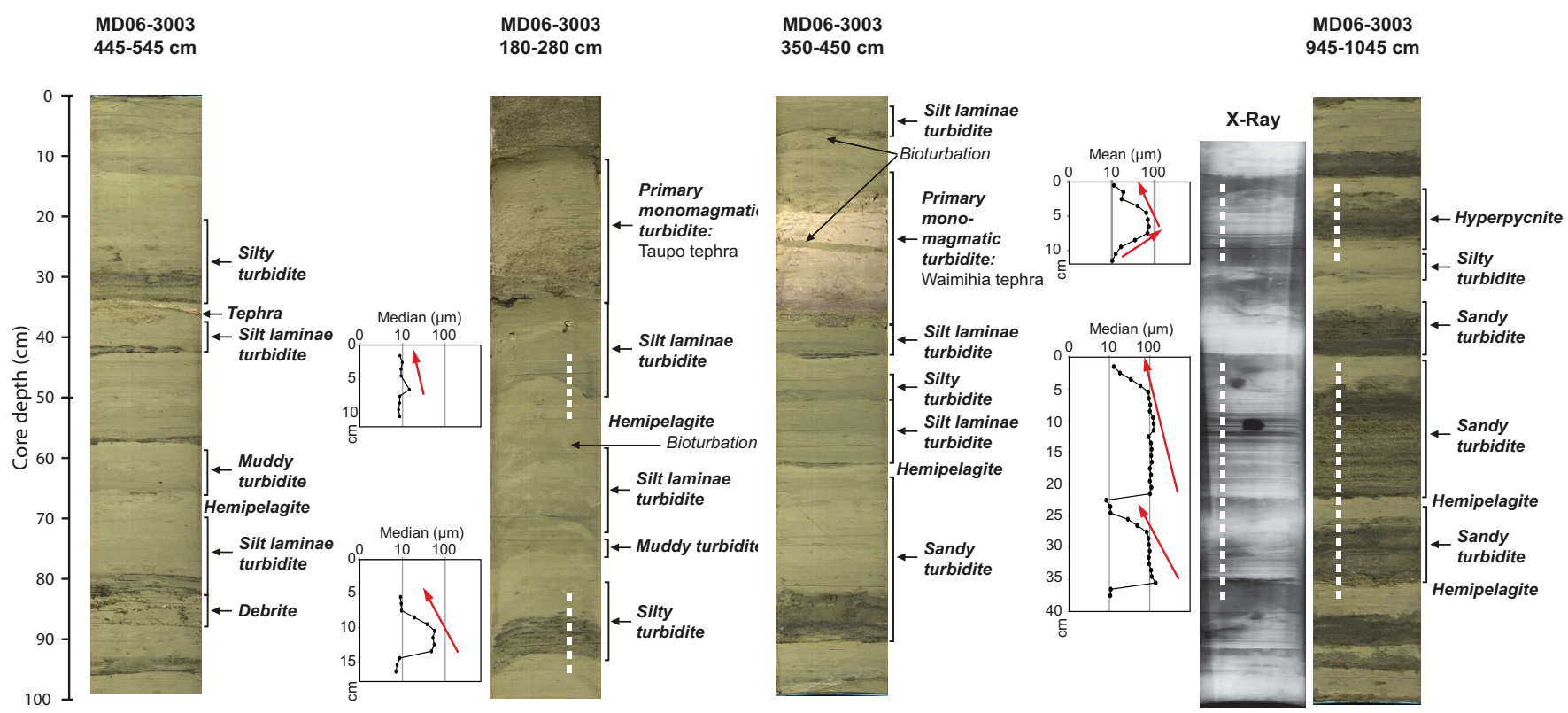

Fig. 3. Main lithofacies identified in cores from high resolution photos, grain size analysis and X-ray: hemipelagite, tephra, turbidite and debris flow (from Pouderoux et al., 2012). Grain-size data are presented for some turbidites (either the median or the mean values). Samples are taken at $<1 \mathrm{~cm}$ intervals; position of samples is indicated by dashed lines on photos.

former four as its basal reverse-graded unit is underlying the normal graded sequence. Monomagmatic turbidites are identified as silty to sandy turbidites made up of $>90 \%$ of volcanoclastic grains from a single volcanic eruption. Although their coarse basal grain-size differs markedly from the tephra lithofacies, their emplacement directly after the volcanic eruption makes them datable as a pure tephra.

\section{Data and methods}

\subsection{Cores analyses}

The present study is based on two giant piston cores (MD063002 and MD06-3003) collected in the Paritu Turbidite System using the R/V Marion-Dufresne capability (Proust et al., 2006, 2008). The cores targeted the deep-sea sedimentation deposited since the Last Glacial Maximum (LGM) (Fig. 2a; Table 2). MD06-3003 was collected in the Paritu Trough in water depth of $\sim 1400 \mathrm{~m}$, at the front of the PDA, and MD063002 was collected in the Lower Paritu Basin in water depth of $\sim 2300 \mathrm{~m}$. High-resolution $3.5 \mathrm{kHz}$ seismic reflection data and EM300 multibeam bathymetry allowed assessment of the sampling sites in terms of homogeneity and presence of sub-seafloor reflectors indicative of turbidites and tephras (Fig. 2b).

Sedimentological analysis, undertaken on the two cores, included detailed visual description, $\mathrm{X}$-ray radiographs of split cores, grain-size analyses of selected intervals and compositional characterization of the sediments (Pouderoux et al., 2012). Geotek Multi-Sensor Track (MST) geophysical analysis on split cores provided continuous gamma density, magnetic susceptibility and P-wave velocity measurements as well as high definition pictures.

Total organic carbon (TOC), $\mathrm{C} / \mathrm{N}$ ratios and $\delta^{13} \mathrm{C}$ measurements were undertaken on 64 silty clay samples taken in MD06-3003 from well- identified hemipelagites and turbidite tails using the colour proxy defined by Pouderoux et al. (2012) in the Ruatoria re-entrant, $100 \mathrm{~km} \mathrm{NE}$ of the study site. Measurements of $\sim 1 \mathrm{~g}$ bulk samples were used to (1) ascertain the differentiation between hemipelagite and turbidite tails in the Poverty re-entrant, and (2) estimate the origin of the sediment involved in turbidites. All samples were specifically prepared and analysed for $\% \mathrm{TOC}, \% \mathrm{~N}$ to calculated $\mathrm{C} / \mathrm{N}$ ratios, and $\delta^{13} \mathrm{C}$. Sediments were acidified with an excess volume of $10 \%$ hydrochloric acid, rinsed with deionised water, and dried at $60^{\circ}$. Ground sediments were weighed, and carbon and nitrogen stable isotope analyses carried out on a NA $1500 \mathrm{~N}$ elemental analyser (Fisons Instruments, Rodano, Italy) linked to a Delta ${ }^{\text {Plus }}$ continuous flow isotope ratio mass spectrometer (Thermo-Fisher Scientific, Bremen, Germany). Percent $\mathrm{OC}$ and $\% \mathrm{~N}$ values were calculated relative to a solid laboratory reference standard of DL-Leucine (DL-2-Amino4-methylpentanoic acid, C6H13NO2, Lot 127H1084, Sigma, Australia) for each run. Internal standards were routinely checked against that of the National Institute of Standards and Technology (NIST) to maintain accuracy. Repeat analysis of NIST standards produced data accurate to within $0.3 \%$ o for $\delta^{13} \mathrm{C}$ and a precision better than $0.2 \%$ for $\mathrm{N}$ and $0.3 \%$ for $\mathrm{C}$. For $\% \mathrm{~N}$ and $\mathrm{C}$ content, data are accurate to within 
Table 2. MD06 piston cores localisation and sedimentological characteristics.

\begin{tabular}{|c|c|c|c|c|c|c|c|c|}
\hline \multirow[t]{2}{*}{ Core } & \multicolumn{2}{|c|}{ Longitude } & \multicolumn{2}{|c|}{ Latitude } & \multirow{2}{*}{$\begin{array}{r}\text { Water } \\
\text { depth }(m)\end{array}$} & \multirow{2}{*}{$\begin{array}{r}\text { Core } \\
\text { length }(\mathrm{m})\end{array}$} & \multicolumn{2}{|c|}{ Composition* } \\
\hline & deg. & $\min$. & deg. & $\min$. & & & $\mathrm{T}$ & $\mathrm{H}$ \\
\hline MD 06-3002 & 39 & 7.83 & 178 & 40.31 & 2305 & 12 & $75 \%$ & $25 \%$ \\
\hline MD 06-3003 & 39 & 2.79 & 178 & 32.17 & 1398 & 12.88 & $77 \%$ & $23 \%$ \\
\hline
\end{tabular}

*: average proportion of turbidites $(\mathrm{T})$ and hemipelagites $(\mathrm{H})$

$0.4 \%$, with a precision usually better than $0.3 \%$ for $\mathrm{N}$ and $0.2 \%$ for $\mathrm{C}$.

\subsection{Age models}

Robust age models are required to determine the age and return time of the turbidites identified in the cores. Turbidites cannot be dated directly as they consist of remobilised material emplaced instantaneously. The background hemipelagite deposited beneath and above a turbidite layer usually provides datable material. The large number of turbidites in both cores ( 5 to 6 turbidites per meter; Pouderoux et al., 2012) prevented us from developing a systematic down-core age record. Time constraints are provided by 28 absolute ages $\left(1\right.$ age $\mathrm{m}^{-1}$ in average) determined by Pouderoux et al. (2012) from tephra identification and AMS ${ }^{14} \mathrm{C}$ radiocarbon (Tables 3 and 4). The youngest date obtained in MD063002 is $6060{ }^{14} \mathrm{C}$ years at $0.63 \mathrm{~m}$ (Table 4). No major disturbances were identified downcore, and MD06-3002 contains a continuous sedimentary record up to $14301{ }^{14} \mathrm{C}$ yr at $10.3 \mathrm{~m}$. MD06-3003 covers a complete chronology from $842{ }^{14} \mathrm{C} \mathrm{yr}$ at $0.25 \mathrm{~m}$ to $13800{ }^{14} \mathrm{C}$ yr at its base. Sediments younger than $842{ }^{14} \mathrm{C}$ yr were either not recovered or unusable.

The age of each turbidite is estimated using the statistical approach developed in the OxCal software (v. 4.1; Bronk Ramsey, 2008). OxCal interpolates the sedimentation rate along the cores, ascertains the age of each time marker (tephra or ${ }^{14} \mathrm{C}$ ages) and calculates the age of sediment at a given depth. The depth corresponds to the cumulated depth of hemipelagite (or corrected depth), which is deposited continuously and calculated by removing all turbidites and tephra layers from the total core length. We assumed there was negligible erosion at the base of the turbidites, as these are fine-grained, they have a reduced thickness (usually $<10 \mathrm{~cm}$ ) and sedimentation has been relatively homogeneous since $18 \mathrm{ka}$ (Pouderoux et al., 2012). Hence, we believe the hemipelagite-cumulated depth for each core represents the entire sedimentation time without major hiatus. OxCal is usually utilised to reduce the age uncertainties provided by ${ }^{14} \mathrm{C}$ ages systematically taken below turbidites (Goldfinger et al., 2003, 2007, 2008; Gràcia et al., 2010) and is adapted in this study to date individual turbidites.

The age model is built following the procedure developed by Gràcia et al. (2010) from the OxCal P_Sequence deposition model, a Bayesian function that assimilates sedimentation as a random process following a Poisson law (Bronk Ramsey, 2008). The resulting age model increases uncertainties with distance from the time constraints. The parameters required to generate the $P$ Sequence model are the uncalibrated ${ }^{14} \mathrm{C}$ ages and respective $\Delta R$, or the calibrated tephra ages, with their corresponding corrected depth. The model boundaries are provided by the top and base of the core. The program extrapolates the age of these boundaries with the constraint that the top of the core cannot be younger than 0 yr. The regularity of the sedimentation is determined by the $k$ parameter: the higher the $k$ parameter, the more linear the deposition along core and the smaller the turbidite age uncertainties. The $k$ parameter is generally lower than 2 . The model then refines the age of each sample following the regularity of the sedimentation. The hemipelagite sedimentation is assumed constant and homogeneous for the time period considered in the region (Carter et al., 2008; Pouderoux et al., 2012), so that we were able to set the highest possible values of $k$ that provided a modelled age of each time marker within $1 \sigma$ of the calibrated age. The model finally calculates the age of each corrected depth corresponding to a turbidite and generates the $68.2 \%$ and $95.4 \%$ probability age ranges $(1 \sigma$ and $2 \sigma$ ). In the following sections, ages are reported with $2 \sigma$ uncertainties.

\subsection{Core correlations}

The correlation of turbidites between the two cores is a fundamental step as it provides essential criteria for discussing their origin, implementation and triggering mechanisms. Correlation is primarily based on the timing and ages, hence the absolute necessity to generate a robust age model. Because of the large number of turbidites in the cores, correlations were rarely unequivocal. To refine correlations, we used the peak-to-peak correlation of geophysical properties, the relative thickness from the nearest time markers, usually tephra layers, and the turbidite facies. Peak-to-peak correlation suggests that correlative turbidites are similar in composition and share the same source area (Goldfinger et al., 2007, 2008) and is therefore an excellent tool for correlating turbidites from one core to the other. 
Table 3. Radiocarbon ages retrieved from cores MD06-3002 and MD06-3003 (Pouderoux et al., 2012).

\begin{tabular}{lrrrr}
\hline Core & $\begin{array}{r}\text { Orig. } \\
\text { Depth }(\mathrm{cm})\end{array}$ & $\begin{array}{r}\text { Corr. } \\
\text { Depth }(\mathrm{cm})\end{array}$ & $\begin{array}{r}{ }^{14} \mathrm{C} \text { age } \\
(\mathrm{yr})\end{array}$ & $\begin{array}{r}2 \sigma \text { error } \\
(\mathrm{yr})\end{array}$ \\
\hline 63.35 & 19.35 & 6060 & 40 \\
& 138 & 56.5 & 7036 & 55 \\
MD06-3002 & 162.55 & 63.05 & 7210 & 40 \\
& 584.5 & 176 & 10250 & 75 \\
& 728.4 & 205.9 & 12621 & 60 \\
& 757.4 & 208.9 & 12823 & 60 \\
& 944.85 & 236.35 & 13313 & 75 \\
& 1027.35 & 243.35 & 14301 & 60 \\
\hline \multirow{4}{*}{ MD06-3003 } & 25.5 & 20.5 & 842 & 20 \\
& 63.05 & 31.05 & 1415 & 45 \\
& 129.05 & 81.05 & 1790 & 35 \\
& 271.7 & 114.7 & 2780 & 30 \\
& 306.05 & 125.05 & 3170 & 35 \\
& 802.5 & 243.5 & 10234 & 55 \\
892.5 & 259.5 & 12480 & 90 \\
& 921 & 263.7 & 12850 & 65 \\
& 1028.5 & 273 & 12998 & 75 \\
& 1154.2 & 281.2 & 13502 & 75 \\
1253.75 & 288.75 & 13800 & 65 \\
\hline & & &
\end{tabular}

Table 4. Tephras identification in cores MD06-3002 and MD06-3003 (Pouderoux et al., 2012) with the corresponding eruption name and age (after Lowe et al., 2008).

\begin{tabular}{lrrlr}
\hline Core & $\begin{array}{r}\text { Orig. } \\
\text { depth }(\mathrm{cm})\end{array}$ & $\begin{array}{r}\text { Corr. } \\
\text { depth }(\mathrm{cm})\end{array}$ & $\begin{array}{l}\text { Tephra } \\
\text { identification }\end{array}$ & $\begin{array}{r}\text { Calibrated age } \\
(\mathrm{yr} \mathrm{BP} \pm 2 \sigma)\end{array}$ \\
\hline \multirow{4}{*}{ MD06-3002 } & 255 & 92.5 & Mamaku & $8005 \pm 45$ \\
& 430 & 131 & Rotoma & $9505 \pm 25$ \\
& 499 & 158.5 & Opepe & $10075 \pm 155$ \\
& 782 & 212.5 & Waiohau & $13635 \pm 165$ \\
\hline \multirow{3}{*}{ MD06-3003 } & 205 & 97 & Taupo & $1717 \pm 13$ \\
& 481 & 164.5 & Whakatane & $5530 \pm 60$ \\
& 606 & 208.5 & Mamaku & $8005 \pm 45$ \\
& 710 & 236 & Rotoma & $9505 \pm 25$ \\
& 736 & 241.5 & Opepe & $10075 \pm 155$ \\
\hline
\end{tabular}

\subsection{Terminology}

In the sedimentary record of the Paritu Turbidite System, we distinguish stacked turbidites from isolated turbidites. Stacked turbidites consist of two or more successive turbidites with no intervening hemipelagites. They represent successive turbidity currents emplaced "instantaneously" at geological time scale since erosion is considered negligible. Isolated turbidites are systematically under- and over-lain by hemipelagites. Because tephras usually settle within days to months after a volcanic eruption (e.g. Wiesner et al., 1995), they are used as proxy for time between successive turbidites. Both stacked and isolated turbidites represent a single depositional event, called a turbidite event $(\mathrm{T} x)$, as the presence of intervening hemipelagite or tephra is the only guarantor that time has elapsed between two successive turbidites.

The correlation of turbidite events between the two cores enables us to characterise their deposition as basin events, isolated events, or undetermined events. Basin events are synchronous turbidite events recorded in both cores. They are labelled $\mathrm{P} x, x$ being the event sequential number in the basin from younger (P1) to older. A basin event is recognized by synchronous turbidites in both cores. As a result, the age of a basin event is given by the common age range from both cores. This methodology helps to refine the age and reduce the $2 \sigma$ range. Isolated events are depositional events observed in only one core. Undetermined events are those 
that cannot be correlated due to a lack of recovered material in the neighbouring core.

\section{Results}

\subsection{Sediment characteristics}

Cores MD06-3002 and MD06-3003 contain the four main lithofacies recognised by Pouderoux et al. (2012):

- Tephras: four and five tephras are respectively recorded in MD06-3002 and MD06-3003 (Table 4). The Mamaku, Rotoma and Opepe tephras were identified in both cores. Tephras have generally high density $\left(>1.8 \mathrm{~g} \mathrm{~cm}^{-2}\right)$, MS ( $\left.>40 \mathrm{SI}\right)$, and P-wave velocity $\left(>1300 \mathrm{~m} \mathrm{~s}^{-1}\right)$ with sharp variations at the base and top boundaries. We assume that pure tephras originate from ash-fall coincident with New Zealand Central Volcanic Region volcanic eruptions (Wiesner et al., 1995; Carter et al., 1995).

- Debrites: only two debrites are identified in MD063003 at $5.30 \mathrm{~m}$ and $12.85 \mathrm{~m}$. The debrite-turbidite couplet pattern observed at $5.30 \mathrm{~m}$ may be due either to the deposition of two distinct gravity flows or to the deposition of a single gravity flow showing hybrid behaviour (Haughton et al., 2009). The latter option is preferred since similar stacked deposits are recognised for slope failure-induced gravity flows (e.g. Schnellmann et al., 2002).

- Hemipelagites are characterised by low density $\left(\sim 1.8 \mathrm{~g} \mathrm{~cm}^{-2}\right)$, P-wave $\sim 1300 \mathrm{~m} \mathrm{~s}^{-1}$ in MD06-3003 and $1400 \mathrm{~m} \mathrm{~s}^{-1}$ in MD06-3002, and MS $\sim 10 \mathrm{SI}$ in MD06-3003 and 60 SI in MD06-3002.

- Turbidites: there are 100 turbidites organised into 72 turbidite events (T1 to T72, Table 5) in MD063002, and 101 turbidites in MD06-3003, organised in 68 turbidite events (T1 to T68). Turbidite thicknesses are $<15 \mathrm{~cm}$ and $<24 \mathrm{~cm}$ in MD06-3002 and MD06-3003, respectively. Turbidites have high density ranging from 1.8 to $2.2 \mathrm{~g} \mathrm{~cm}^{-2}$, high magnetic susceptibility ranging 10-100 SI in MD06-3003 and 60-120 SI in MD063002 , and $\mathrm{P}$-wave velocity ranging $1300-1500 \mathrm{~m} \mathrm{~s}^{-1}$ in MD06-3003 and 1400-1600 $\mathrm{m} \mathrm{s}^{-1}$ in MD06-3002. All turbidites in this study are interpreted as deposited by low to medium density turbidity currents as defined by Stow and Shanmugam (1980) and Bouma (1962). Only six turbidites recognised as basal reverse-graded turbidites were interpreted as hyperpycnites in MD063003 (i.e. flood-induced turbidites deposited by a hyperpycnal flow, following the definition of Mulder et al., 2003).

\subsection{Age model}

The age vs. depth plot from the ten calibrated dates obtained from MD06-3002 (Pouderoux et al., 2012) shows a nonlinear downcore trend, so we use a low $k$ parameter $(k=0.4)$ in the OxCal deposition model, which implies high age uncertainties between time markers (Fig. 4a). The $2 \sigma$ age range of each turbidite event is then relatively high ranging from 25 to $757 \mathrm{yr}$. In MD06-3003, the strong disturbance in the upper $1.50 \mathrm{~m}$ (corrected depth) resulted in two downcore trends in the age model (Fig. 4b and c) and very high age uncertainties when using one single $k$ parameter $(k=0.1)$. The $1.50 \mathrm{~m}$ mark is highlighted by a $\sim 20 \mathrm{~cm}$-thick primary monomagmatic turbidite, which presumably stopped the downcore propagation of the deformation. The stratigraphic position of this layer between the $3170{ }^{14} \mathrm{C}$ years above and the Whakatane tephra ( $5530 \pm 60 \mathrm{yr} \mathrm{BP})$ below suggests that it is related to the Waimihia volcanic eruption $(3410 \pm 40 \mathrm{yr} \mathrm{BP}$, Lowe et al., 2008). Since no other large eruptions are known in the Poverty region at that time (Gerber et al., 2010; Orpin, 2004; Wilson, 1993), we use this age in the model. To better constrain the age of each turbidite event in the core, we used two $P_{\text {sequence }}$ models on either side of the "Waimihia turbidite", with $k=0.2$ in the upper part and $k=2.6$ in the lower part. This results in two mean corrected sedimentation rates of $\sim 10 \mathrm{~cm} \mathrm{kyr}^{-1}$ and $\sim 40 \mathrm{~cm} \mathrm{kyr}^{-1}$ below and above Waimihia, respectively. Although the sedimentation rate in the upper part of the core is exaggerated because of sediment stretching (Fig. 4c), the turbidite event ages generated by the $\mathrm{OxCal}$ model are acceptable since it is constrained by five ${ }^{14} \mathrm{C}$ ages and two tephras over $150 \mathrm{~cm}$. The use of the two age model provides good $2 \sigma$ age range of the turbidite events, which varies from 28 to $439 \mathrm{yr}$.

The age model provides a precise age for each turbidite event (Table 5). The 72 turbidite events recognised in MD063002 are dated between $6144 \pm 386$ and $17729 \pm 701 \mathrm{yr} \mathrm{BP}$. There were 38 turbidites deposited during the Holocene (0-11.6 kyr), among which 4 during the Late Holocene at $6144 \pm 386,6397 \pm 227,6600 \pm 224$, and $6903 \pm 277 \mathrm{yr}$ BP. The remaining 30 occurred during the Late Pleistocene between $11623 \pm 436$ and $17729 \pm 701 \mathrm{yrBP}$. The 68 turbidite events from MD06-3003 are dated from 819 \pm 191 to $16621 \pm 439 \mathrm{yr} \mathrm{BP}$. Forty-four were deposited during the Holocene, among which 27 during the Late Holocene. The remaining 28 occurred during the Late Pleistocene between $11659 \pm 348$ and $16621 \pm 439 \mathrm{yr} \mathrm{BP}$.

\subsection{Core correlations}

Excellent peak-to-peak correlations of geophysical properties generate a robust correlation of turbidite events, despite the complex overlap of their $2 \sigma$ age ranges (Fig. 5a and b). In particular, geophysical properties provide a means to correlate turbidite events composed of stacked turbidites. For instance, the peaks in the density and the magnetic 
Table 5. Summary of turbidite event correlation, showing the name, mean age and the $2 \sigma$ error bar (yr BP) of each basin event, with their corresponding turbidite events. The two intervals Int 1 and Int 2 are reported. Basin events are characterized by their origin: slope failures (sf), volcanic eruptions (v) or floods (f). Isolated events in each core each are in italics.

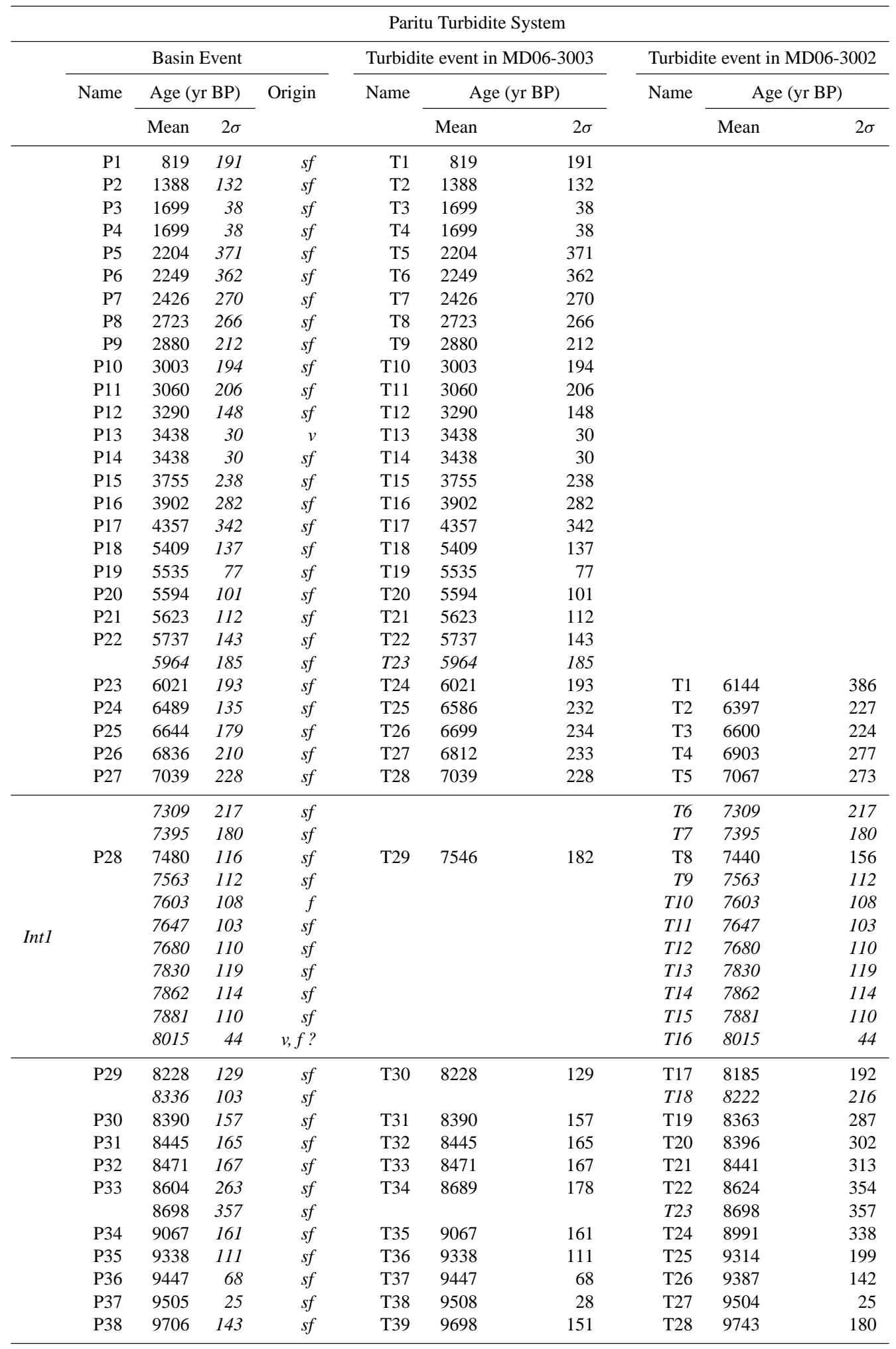


Table 5. Continued.

\begin{tabular}{|c|c|c|c|c|c|c|c|c|c|c|}
\hline & \multicolumn{10}{|c|}{ Paritu Turbidite System } \\
\hline & \multicolumn{4}{|c|}{ Basin Event } & \multicolumn{3}{|c|}{ Turbidite event in MD06-3003 } & \multicolumn{3}{|c|}{ Turbidite event in MD06-3002 } \\
\hline & \multirow[t]{2}{*}{ Name } & \multicolumn{2}{|c|}{ Age (yr BP) } & \multirow[t]{2}{*}{ Origin } & \multirow[t]{2}{*}{ Name } & \multicolumn{2}{|c|}{ Age (yr BP) } & \multirow[t]{2}{*}{ Name } & \multicolumn{2}{|c|}{ Age (yr BP) } \\
\hline & & Mean & $2 \sigma$ & & & Mean & $2 \sigma$ & & Mean & $2 \sigma$ \\
\hline & P39 & 9868 & 122 & $s f$ & $\mathrm{~T} 40$ & 9813 & 178 & T29 & 9941 & 195 \\
\hline & & 10020 & 185 & $s f$ & & & & T30 & 10020 & 185 \\
\hline & P40 & 10155 & 129 & $s f$ & T41 & 10169 & 143 & $\mathrm{~T} 31$ & 10140 & 144 \\
\hline & P41 & 10155 & 129 & $s f$ & $\mathrm{~T} 42$ & 10169 & 143 & $\mathrm{~T} 32$ & 10140 & 144 \\
\hline & P42 & 10169 & 143 & $s f$ & $\mathrm{~T} 42$ & 10169 & 143 & $\mathrm{~T} 33$ & 10308 & 285 \\
\hline & $\mathrm{P} 43$ & 10401 & 297 & $s f$ & $\mathrm{~T} 43$ & 10452 & 348 & $\mathrm{~T} 34$ & 10377 & 322 \\
\hline & P44 & 10501 & 299 & $s f$ & $\mathrm{~T} 43$ & 10452 & 348 & $\mathrm{~T} 35$ & 10613 & 411 \\
\hline & P45 & 10579 & 220 & $s f$ & $\mathrm{~T} 43$ & 10452 & 348 & T36 & 10787 & 428 \\
\hline & P46 & 10606 & 193 & $s f$ & $\mathrm{~T} 43$ & 10452 & 348 & T37 & 10842 & 429 \\
\hline \multirow{2}{*}{\multicolumn{2}{|c|}{ P47 }} & 11207 & 362 & $s f$ & $\mathrm{~T} 43$ & 10452 & 348 & T38 & 11207 & 362 \\
\hline & & 11515 & 328 & $s f$ & & & & T39 & 11623 & 436 \\
\hline & P48 & 11532 & 310 & $f$ & T44 & 11511 & 332 & $\mathrm{~T} 40$ & 11685 & 463 \\
\hline & P49 & 11659 & 348 & $s f$ & $\mathrm{~T} 45$ & 11659 & 348 & $\mathrm{~T} 41$ & 11802 & 505 \\
\hline & & 11868 & 534 & $s f$ & & & & $T 42$ & 11868 & 534 \\
\hline & P50 & 12081 & 378 & $s f$ & T46 & 12081 & 378 & $\mathrm{~T} 43$ & 11992 & 557 \\
\hline & P51 & 12518 & 242 & $s f$ & $\mathrm{~T} 47$ & 12641 & 365 & T44 & 12170 & 590 \\
\hline & P52 & 12698 & 264 & $s f$ & $\mathrm{~T} 48$ & 12785 & 351 & $\mathrm{~T} 45$ & 12357 & 604 \\
\hline & & 13063 & 309 & $s f$ & T49 & 13065 & 311 & & & \\
\hline & P53 & 13106 & 265 & $f$ & T50 & 13138 & 297 & $\mathrm{~T} 46$ & 12795 & 576 \\
\hline & P54 & 13357 & 238 & $s f$ & T51 & 13357 & 238 & T47 & 13101 & 497 \\
\hline & P55 & 13490 & 213 & $s f$ & T52 & 13490 & 213 & $\mathrm{~T} 48$ & 13284 & 420 \\
\hline \multirow[t]{31}{*}{ Int 2} & & 13637 & 152 & $s f$ & & & & T49 & 13484 & 306 \\
\hline & & 13648 & 163 & $s f$ & & & & T50 & 13648 & 163 \\
\hline & & 13701 & 216 & $s f$ & & & & T51 & 13781 & 296 \\
\hline & & 13714 & 203 & $s f$ & & & & T52 & 13885 & 374 \\
\hline & & 13729 & 189 & $s f$ & & & & T53 & 13974 & 434 \\
\hline & P56 & 13736 & 181 & $s f$ & T53 & 13699 & 219 & T54 & 14020 & 465 \\
\hline & P57 & 13831 & 187 & $s f$ & T54 & 13806 & 213 & T55 & 14204 & 560 \\
\hline & & 13967 & 225 & $s f$ & $T 55$ & 13967 & 225 & & & \\
\hline & & 14071 & 245 & $s f$ & T56 & 14071 & 245 & & & \\
\hline & & 14275 & 275 & $f$ & T57 & 14275 & 275 & & & \\
\hline & & 14480 & 290 & $s f$ & $T 58$ & 14480 & 290 & & & \\
\hline & P58 & 14685 & 295 & $s f$ & T59 & 14685 & 295 & T56 & 14796 & 733 \\
\hline & P59 & 14685 & 295 & $s f$ & & 14685 & 295 & T57 & 14883 & 750 \\
\hline & & 14789 & 290 & $s f$ & $T 60$ & 14789 & 290 & & & \\
\hline & P60 & 14890 & 295 & $s f$ & T61 & 14890 & 295 & T58 & 15157 & 757 \\
\hline & & 14940 & 306 & $s f$ & T62 & 14940 & 306 & & & \\
\hline & P61 & 14993 & 317 & $s f$ & $\mathrm{~T} 63$ & 14993 & 317 & T59 & 15342 & 741 \\
\hline & & 15500 & 366 & $s f$ & T64 & 15500 & 366 & & & \\
\hline & P62 & 15549 & 369 & $s f$ & T65 & 15549 & 369 & T60 & 15706 & 643 \\
\hline & P63 & 15849 & 388 & $s f$ & T66 & 15849 & 388 & T61 & 15964 & 675 \\
\hline & P64 & 15948 & 393 & $s f$ & T67 & 15948 & 393 & T61 & 15964 & 675 \\
\hline & P65 & 16140 & 398 & $s f$ & T68 & 16140 & 398 & T61 & 15964 & 675 \\
\hline & P66 & 16292 & 295 & $s f$ & T69 & 16189 & 398 & T62 & 16541 & 544 \\
\hline & P67 & 16451 & 319 & $s f$ & $\mathrm{~T} 70$ & 16373 & 398 & T63 & 16622 & 490 \\
\hline & & 16451 & 319 & $s f$ & $T 71$ & 16424 & 390 & & & \\
\hline & P68 & 16621 & 439 & $s f$ & $\mathrm{~T} 72$ & 16621 & 439 & T63 & 16622 & 490 \\
\hline & P69 & 16961 & 214 & $s f$ & & & & T64 & 16961 & 214 \\
\hline & P70 & 17171 & 363 & $s f$ & & & & T65 & 17171 & 363 \\
\hline & P71 & 17455 & 523 & $s f$ & & & & T66 & 17455 & 523 \\
\hline & P72 & 17523 & 549 & $s f$ & & & & T67 & 17523 & 549 \\
\hline & P73 & 17729 & 701 & $s f$ & & & & T68 & 17729 & 701 \\
\hline
\end{tabular}



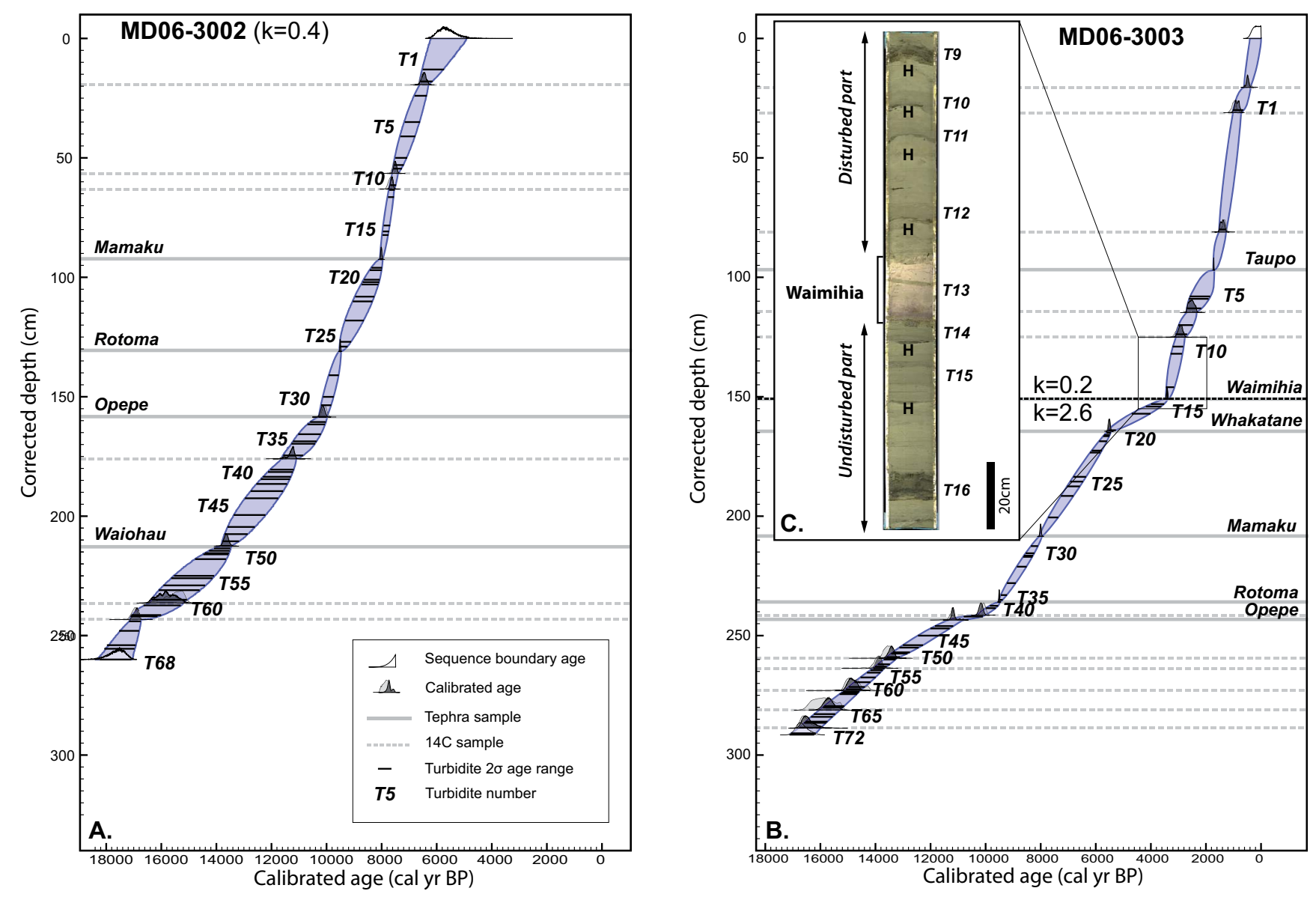

Fig. 4. OxCal age models generated using the OxCal 4.1 software (Bronk Ramsey, 2008) for cores MD06-3002 (A) and MD06-3003 (B). Tx is sequential turbidite number in core. Insert $(\mathbf{C})$ shows the highly stretched sediments above the Waimihia tephra, which justified using two P_sequence in OxCal.

susceptibility (Fig. 5b) show that turbidite event T59 in MD06-3003, which is composed of two successive turbidites, is correlated with turbidite events T56 and T57 in MD06-3002, each composed of isolated turbidites (Fig. 5c). That some turbidite events may be misinterpreted confirms the importance of cores correlations and helps in the recognition of 14 basin events made up of the correlation of one stacked turbidite with many isolated turbidites (Table 5).

The two cores overlap from 6 to $16.6 \mathrm{ka}$, during which 39 and 42 turbidite events are recorded in MD06-3003 and MD06-3002, respectively (Figs. 2a and 5c; Table 5). Over that period, three tephra layers provide absolute time lines and unequivocal correlation ties. We recognised 46 basin events during that time period. Isolated events are identified in both cores: 20 in MD06-3002 and 10 in MD06-3003.

Two short intervals, Int1 (7-8.2 kyr) and Int2 (13.5$14.7 \mathrm{kyr})$, concentrate two-thirds of the isolated events (Fig. 5c, Table 5), and show contrasting sedimentological characteristics from the rest of the cores. Int1 is characterised by one basin event (P28), and 10 isolated events in MD063002 and none in MD06-3003. In MD06-3002, eight of the isolated events (T9-T16) are concentrated at the base of Int1, below P28, whereas MD06-3003 only record hemipelagite (Table 5). Int2 is characterised by two basin events (P56 and P57) and 9 isolated events: four in MD06-3003 (T52-T55) just below basin event P57, during which MD06-3002 only records hemipelagites, and five in MD06-3002 (T47-T52) above basin event P56 with no corresponding hemipelagite in MD06-3003. The Waiohau tephra (13635 $\pm 165 \mathrm{yr} \mathrm{BP})$ identified in MD06-3002 is interbedded in the five isolated events, but is absent in MD06-3003 suggesting erosion in that core. Both intervals (Int1 and Int2) correspond to short time periods (1.2 ka). Because the aim of the study is to define the earthquake trigger of turbidites and generate a paleoseismic record, we removed these two intervals of anomalous sedimentation from the turbidite record.

Forty-three basin events are identified between 6 and $16.6 \mathrm{ka}$, excluding Int 1 and Int2, representing an average return time of $215 \mathrm{yr}$. There are a further 27 undetermined events, distributed as 22 events younger than $6 \mathrm{ka}$ at the top of MD06-3003 and five events older than $16.6 \mathrm{ka}$ at the base of MD06-3002. These undetermined events have an 


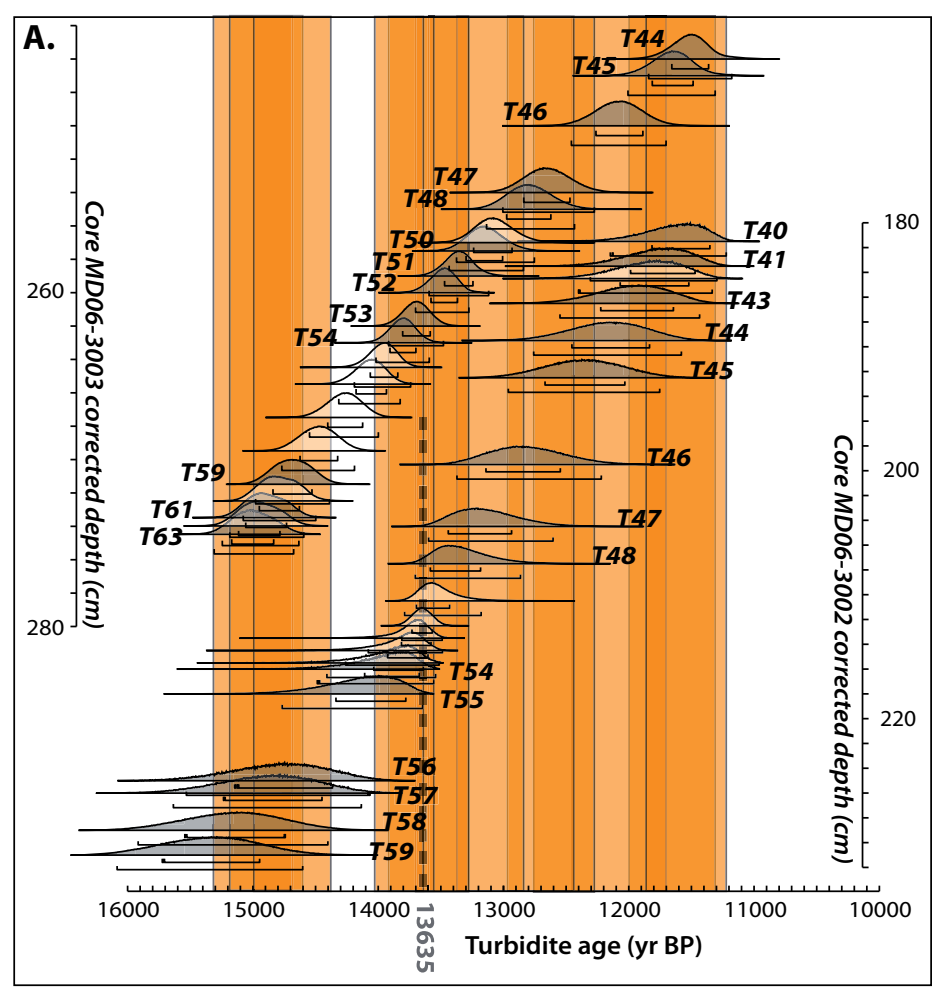

B.

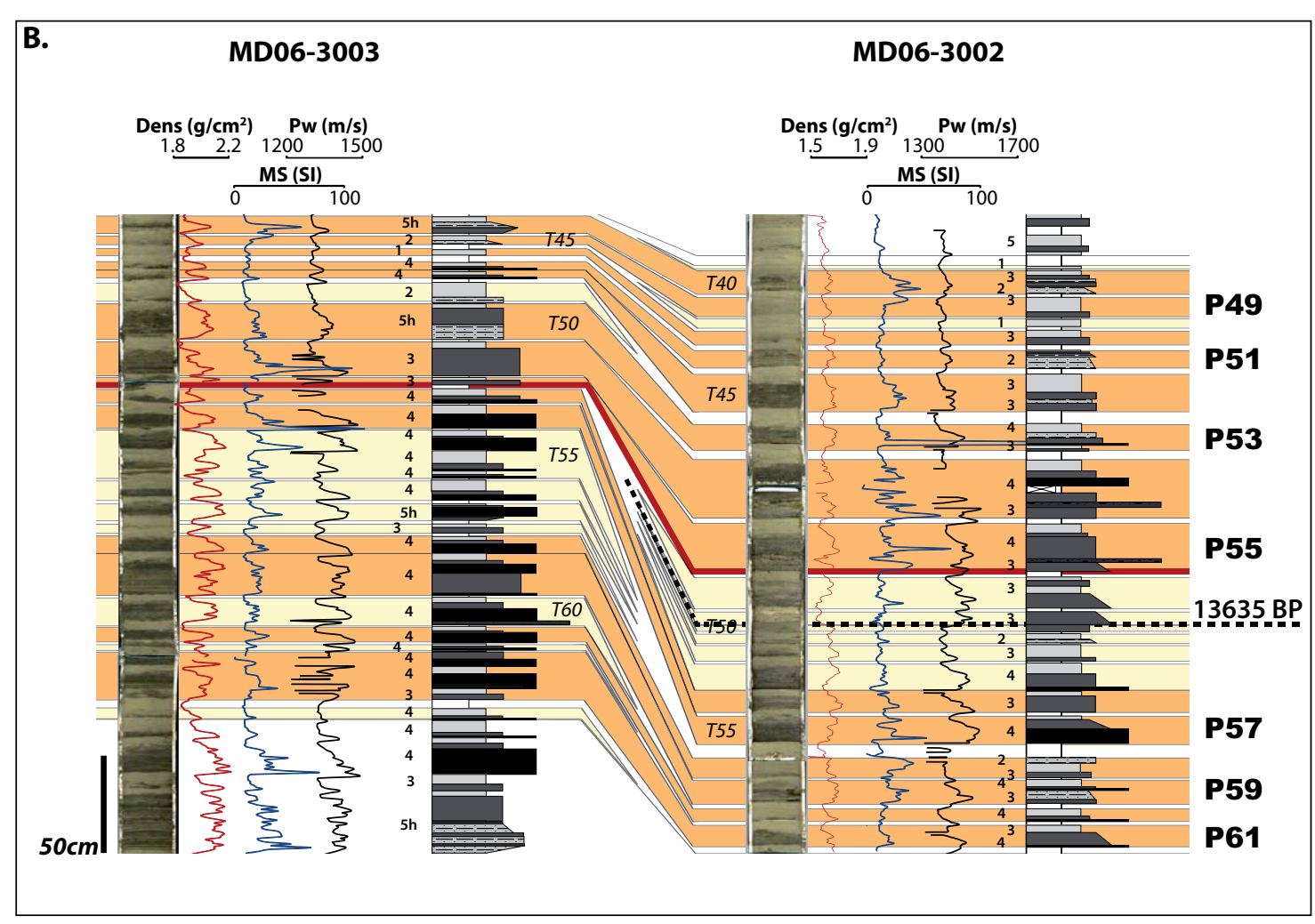

Fig. 5. (A) Example of correlation based on turbidite age only. Each turbidite $(T x)$ is represented by its age distribution. Correlated turbidites in grey; isolated turbidites in white. (B) example of correlation between both cores showing the high definition photo, geophysical MultiSensor Track (MST) data (Dens: density, MS: Magnetic Susceptibility, Pw: P-wave velocity) and synthetic log. Tx: sequential turbidite number in core. Numbers 1 to 5 at the left of the stratigraphic column are turbidite facies. Correlated turbidites $(P x)$ are highlighted in orange. Isolated events in light yellow. 


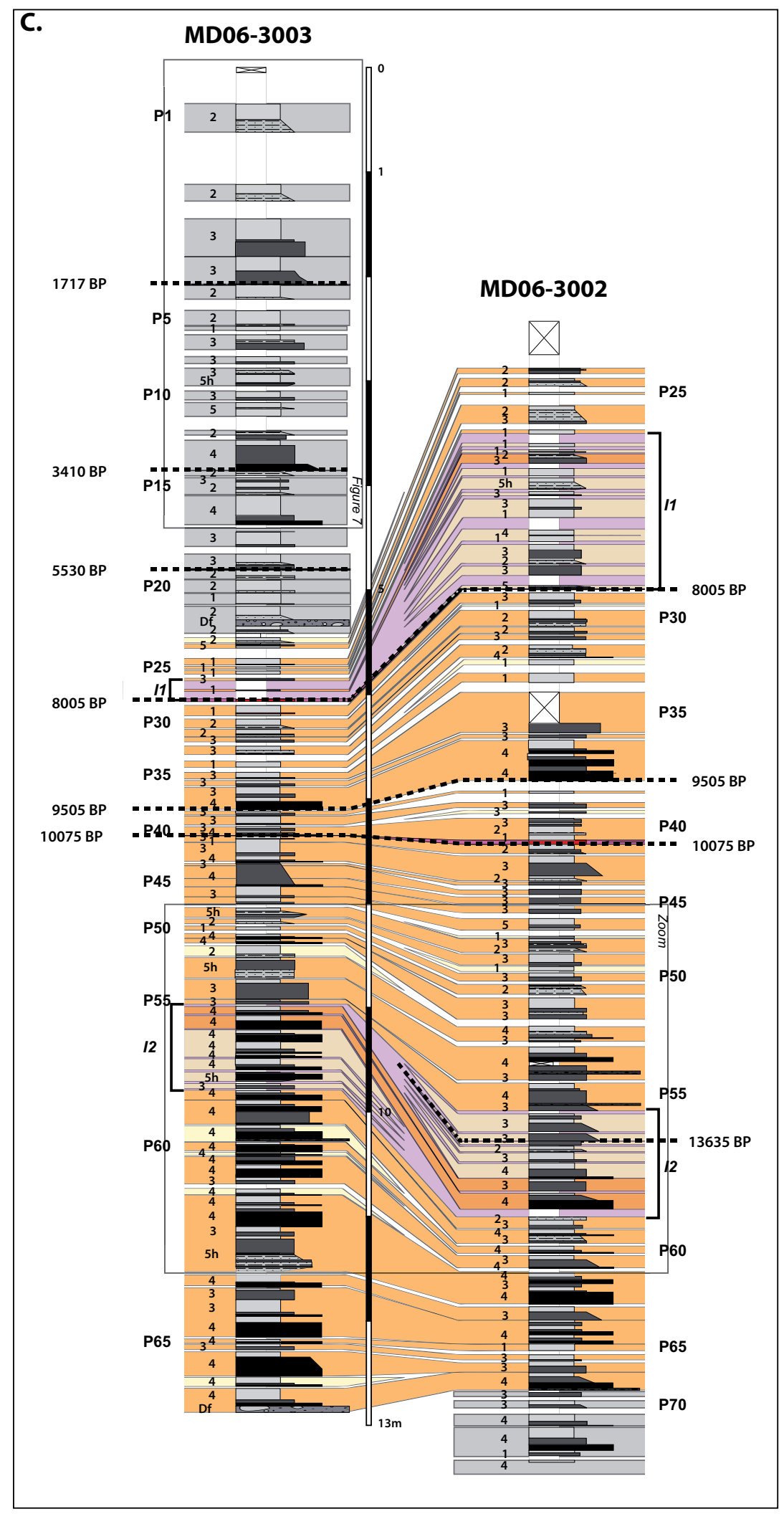

Fig. 5. (C) Turbidite correlation between cores MD06-3002 and MD06-3003, showing the high proportion of basin events and the two short intervals Int 1 and Int 2 of irregular turbidite deposition. Dashed lines are time markers from tephras. 
average return time of 235 and $190 \mathrm{yr}$, respectively. This is very similar to the $215 \mathrm{yr}$ average return time of basin events, which suggests that the 27 undetermined events can be used as proxy for basin events. Therefore, we use a total of 70 basin events recognized between $819 \pm 191$ and $17,729 \pm 701 \mathrm{yr} \mathrm{BP}$. To calculate the mean return, we exclude events occurring during Int 1 and Int2, i.e. we use events P1P27, P29-P55 and P58-P73 (Table 5), which results in a mean return time of $220 \mathrm{yr}$. Between P1 and P27, 27 basin events occurred over a 6220-yr period. Likewise, between P29 and P55 and between P58 and P73, 27 and 16 basin events occurred over 5262 and 3044-yr periods, respectively. The 220 -yr mean return time is calculated from the 67 intervals $(26+26+15)$ over a 14526 -yr period $(6220+5262+3044)$. Mean return times presented in this paper are calculated following this method.

\subsection{Geochemical analysis}

Organic carbon analyses were performed on 12 hemipelagite and 38 turbidite samples, collected in MD06-3003 (Fig. 6a), from 0.46 to $11.5 \mathrm{~m}$, over a $14.7 \mathrm{kyr}$ time period from 0.8 to $15.5 \mathrm{ka}$. The analyses were performed to ascertain the differentiation between hemipelagites and turbidites, to spatially constraint the origin of turbidity currents and to confirm their triggering by earthquake. For that purpose, turbidite samples were taken within basin events, excluding Int 1 , Int 2 and turbidite events related to floods or volcanic eruptions. The samples were sorted into three time periods corresponding to sea level fluctuations and climate oscillations: the Late Holocene from 0 to $7 \mathrm{ka}$ (P1 to P27), the Early Holocene from 7 to $11.6 \mathrm{ka}$ (P29-P47), and the Late Pleistocene from 11.6 to $15.5 \mathrm{ka}$ (P48-P62) (Fig. 6).

The upper $5.5 \mathrm{~m}$ of core MD06-3003 covers the time span from the Late Holocene period of stable climate and sealevel highstand, similar to present-day climato-eustatic conditions. Measured $\delta^{13} \mathrm{C}$ values range from -22.2 to -23.5 , and $\mathrm{C} / \mathrm{N}$ values from 7 to 9 (Fig. 6b). Hemipelagites have higher $\delta^{13} \mathrm{C}$ and lower $\mathrm{C} / \mathrm{N}$ values than turbidites. At each period, hemipelagites and turbidites separate clearly (Fig. 6b and d), which justifies using the colour proxy to characterise hemipelagites. From the Late Pleistocene (11-15.5 kyr) to the Late Holocene (0-7 kyr), hemipelagites and turbidites geochemical signatures show a global trend of increasing $\delta^{13} \mathrm{C}$ and decreasing $\mathrm{C} / \mathrm{N}$ (Fig. $6 \mathrm{~b}$ and d), probably related to the marine transgression.

We compared our results to present-day organic carbon values of hemipelagites sediments (bulk values) provided by the land-sea transect of Brackley et al. (2010). These values are used as a reference for the signature of terrestrial sediments (soil from the floodplain, sample 1 in Fig. 6a), the continental shelf (samples 2 and 3), the gullied upper slope (samples 4 and 5) and the Paritu Trough (sample 6) close to MD06-3003. The $\mathrm{C} / \mathrm{N}$ vs. $\delta^{13} \mathrm{C}$ plot of these samples shows a general increase of $\delta^{13} \mathrm{C}$ (from -27 to -21.5 ) and decrease of $\mathrm{C} / \mathrm{N}$ (from 12 to 9; Fig. 6b) in a seaward direction. These values can be compared with our Late Holocene samples, since the climate and sea level remained roughly constant over the last $7 \mathrm{kyr}$. Late Holocene sediments share similar $\delta^{13} \mathrm{C}$ values with the present-day measurements of the Paritu Trough and the gullied upper slope (Fig. 6b). In particular, Late Holocene and present-day hemipelagites from the Paritu Trough are very similar, and turbidites and the gullied upper slope have corresponding values. $\mathrm{C} / \mathrm{N}$ values from the Late Holocene are clearly lower than the present-day measurements. This may be due to the drastic environmental changes associated with forest clearance from $500-700 \mathrm{yr} \mathrm{BP}$ onwards (H. Neil, personal communication, 2011; McGlone et al., 1994; McGlone and Wilmshurst, 1999). In particular, European colonisation, which began $170 \mathrm{yr}$ ago, caused major increase in sediment discharge to the continental shelf and slope (e.g. Gomez et al., 2007; Gerber et al., 2010; Miller and Kuehl, 2010), which modify the geochemical signature of the sediment.

\section{Discussion}

Here, we show that the turbiditic record is a compelling paleo-earthquake proxy, which provides the means required to derive the age, frequency, source and impact on the slope stability of large and repetitive earthquakes over an 18-kyr period. In the next three sections, we establish the link between turbidites and earthquakes using a rationale based on the progressive characterisation of the turbidites, different from the confluence and synchronicity approach of Goldfinger et al. (2003, 2007, 2008): (1) define the likely triggering mechanisms of turbidites by identifying the source area and the slope failure origin; (2) connect the slope failure trigger with earthquakes so that turbidites can be used as paleoearthquake proxy; and (3) compare the earthquake frequencies deduced from turbidites with those calculated from empirical fault-earthquake relationships to determine a potential list of earthquake sources. In the final section, we discuss the influence of repetitive earthquakes on the occurrence of large debris avalanches in the Paritu Trough.

\subsection{Slope failure origin of basin events}

Some known triggering mechanisms of turbidity currents include slope failures (e.g. Piper et al., 1999), coastal sediment resuspension (e.g. Piper and Normak, 2009; Wright and Friedrichs, 2006), dense shelf water cascades (e.g. Canals et al., 2006), vertical density currents (e.g. Manville and Wilson, 2004) and large floods (e.g. Mulder et al., 2003). That the Paritu channel acts as a sediment pathway between the Paritu Trough and the Lower Paritu (Fig. 2a) is corroborated by the correlation of $>90 \%$ of turbidite events between the two cores. This indicates that any turbidite event originated from the same turbidity current rather than from 

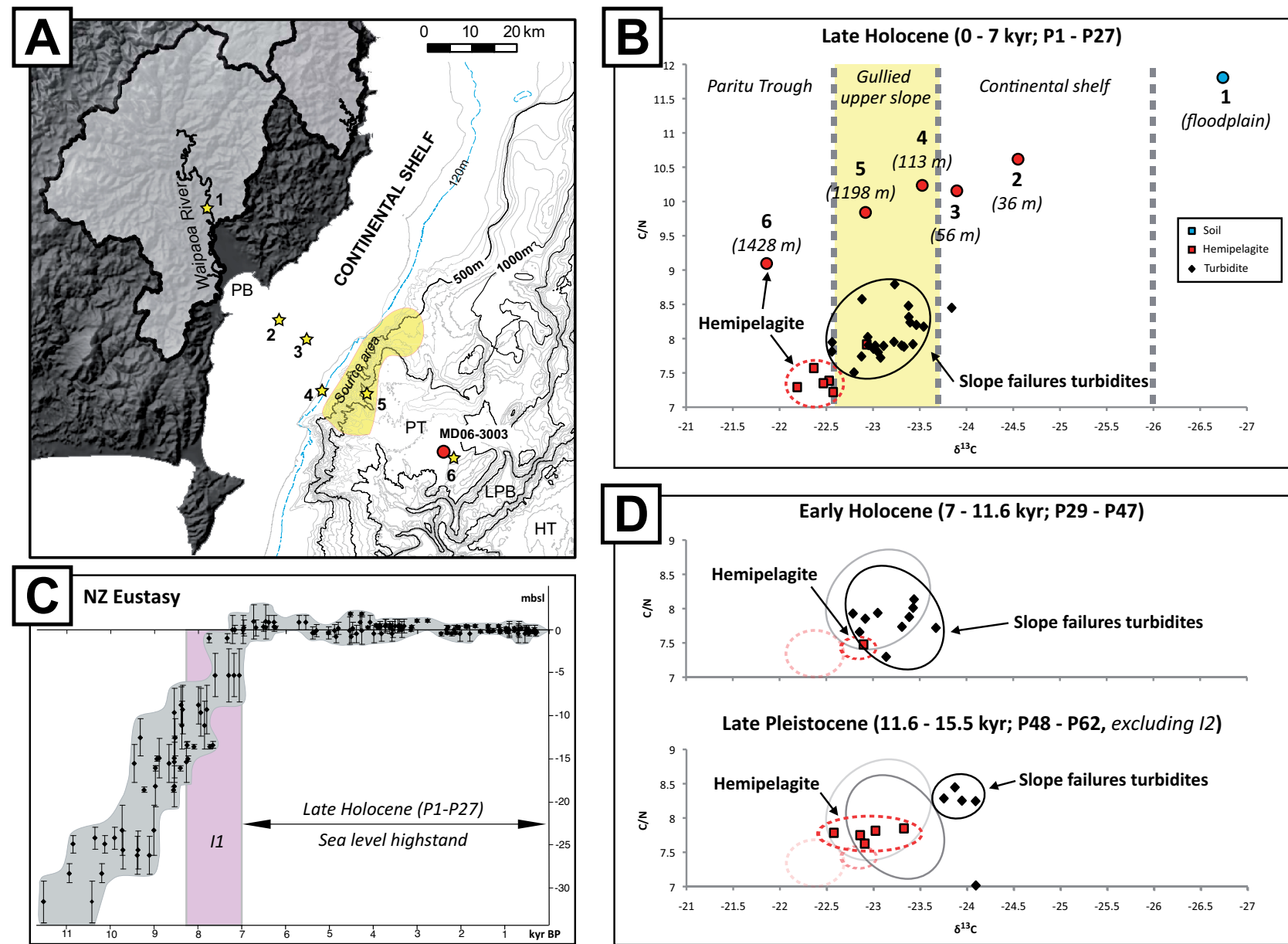

Fig. 5. (A) Bathymetry of the Poverty re-entrant showing the location of core MD06-3003 (red circle) and surface sediment samples from Brackley et al. (2010) (yellow stars). PB: Poverty Bay, PT: Paritu Trough, LPB: Lower Paritu Basin, HT: Hikurangi Trough. (B) Plot showing $\delta 13 \mathrm{C}$ vs. $\mathrm{C} / \mathrm{N}$ values from Brackley et al. (2010) samples (circles) and from MD06-3003 Late Holocene samples. MD06-3003 samples are organised into hemipelagite (red squares) and slope failure turbidites (black diamonds) representing basin events. The black and dashed-red circles circumscribe the two types of samples and are reported in (D) for reference. $\delta 13 \mathrm{C}$ values are depth-dependant and allow an artificially division of the plot into geographic domains: floodplain, shelf, gullied upper slope and Paritu Trough. (C) Holocene eustatic curve for New Zealand from Gibb (1986) and Cochran et al. (2006). Int1 is shown in pink. (D) $\delta 13 \mathrm{C}$ vs. C/N plots for Early Holocene and Late Pleistocene MD06-3003 samples. Transparent circles correspond to samples for earlier time periods (see B). Note the decreasing trend of $\delta 13 \mathrm{C}$ and slight increase of $\mathrm{C} / \mathrm{N}$ with time.

geographically distinct synchronous gravity flows. The three basin events from Int 1 and Int2 are excluded from the record as they are not considered as representative of the overall sedimentary regime. Consequently, all 70 basin events identified between $819 \pm 191$ and $17729 \pm 701 \mathrm{yr}$ BP represent a distinct record of 70 turbidity currents, each originated from, or at least transiting through, the gullied upper slope (i.e. $<1200$ m; Fig. 2a). Amongst them, three events exhibit characteristic sedimentological features and correspond to the sedimentary record of catastrophic floods (typical basal reverse grading sequence of hyperpycnites in P48 and P53) and volcanic eruptions (distinctive sand composition dominated by volcaniclastic material in P13) (Table 5; Pouderoux et al., 2012). These two mechanisms represent only $4 \%$ of the record. The triggering mechanism of the remaining events is therefore attributed to slope failures, coastal sediment resuspension, or dense shelf water cascading. Basin events triggered by the two latter mechanisms usually exhibit a characteristic contribution of shelf material, while slope failures are phenomena occurring on the upper slope and usually contain a signature deeper than the shelf edge ( $>150 \mathrm{~m}$ deep).

The likely origin from the gullied upper slope for the remaining 67 basin events is confirmed by the followings observations. The freshness of the topography indicates that the gullied upper slope has been active in geologically recent times (Mountjoy and Micallef, 2012). Active gullies in the upper slope of the Paritu Turbidite System (Fig. 7c), compared to inactive mature gullies of the Poverty Canyon 

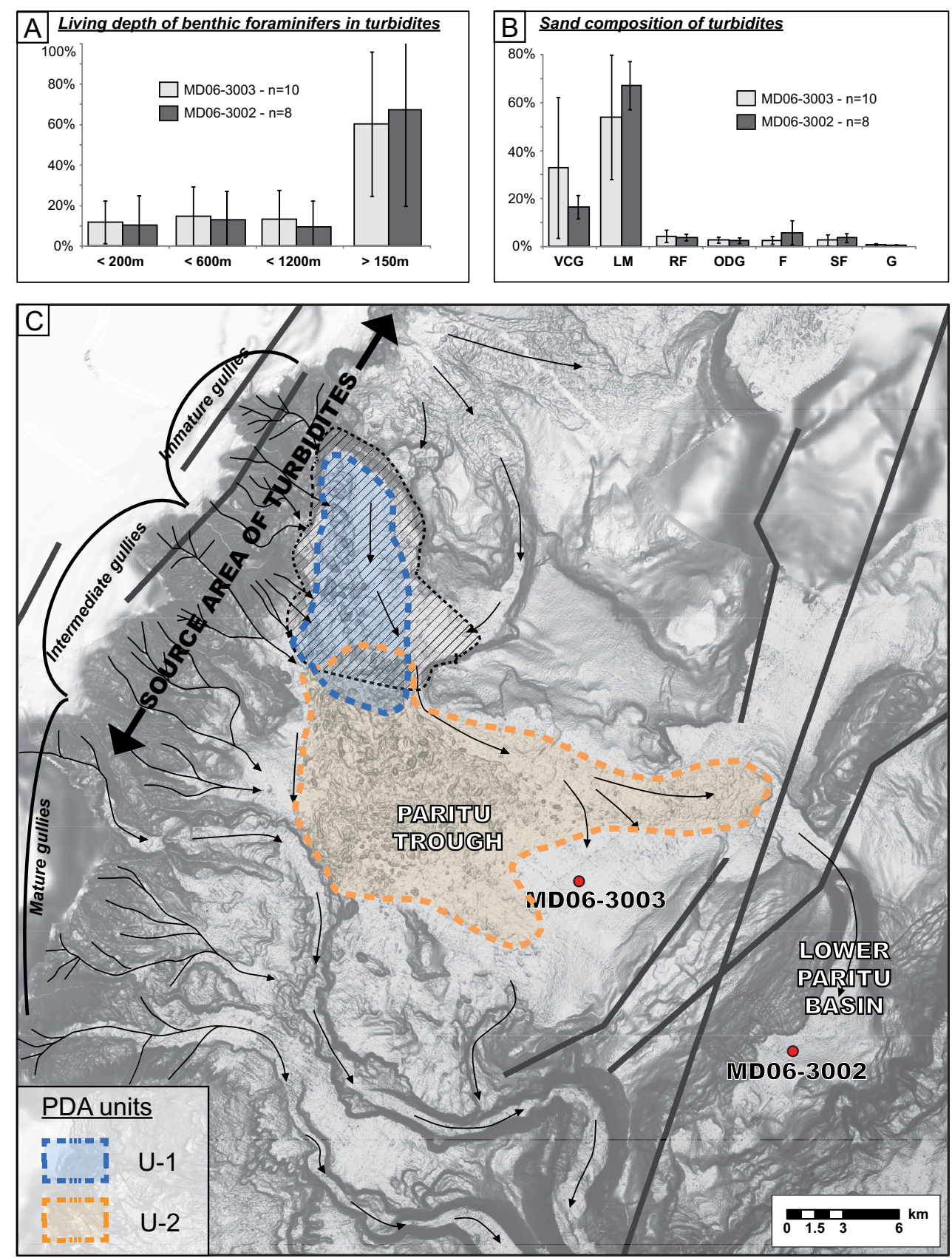

Fig. 6. (A) Turbidite content of benthic foraminifers in a selection of turbidites in both cores ( $n=$ number of sampled turbidites, $\sim 10 \%$ of the total number). Foraminifers have been arranged in four categories following their living depth (Pouderoux et al., 2012). (B) Turbidite sand composition for the same samples as in A. Sand grains are divided in seven categories: VCG: volcaniclastic grains, LM: light minerals, RF: rock fragments, ODG: other detritic grains, F: foraminifers, SF: shell fragments, G: glauconite. (C) Bathymetry of the Paritu Turbidite System showing sediment pathways (black arrows), earthquake source active faults (grey lines), cores (red dots), and the estimated source area for turbidites (gullies from Mountjoy and Micallef, 2012).

system (Orpin et al., 2006; Walsh et al., 2007), suggest that gravity flow activity is concentrated on the Paritu Turbidite System, at least during the Holocene. The $\delta^{13} \mathrm{C}$ signals from basin events and surface sediments from the gullied upper slope have similar ranges (Fig. 6b), suggesting that basin events include reworked material from water depth ranging from 150 to $1200 \mathrm{~m}$ (Fig. 2a). The foraminiferal content (Pouderoux et al., 2012) shows a majority of benthic species from environments deeper than the shelf edge $(>150 \mathrm{~m}$; Fig. 2a) and a very low shelf contribution $(<10 \%$; Fig. 7 a), 
corroborating our interpretation as an upper slope origin for the basin events. Lastly, the sand of basin events is essentially composed of volcaniclastic grains and light minerals (mostly quartz) (Fig. 7b). The lack of clear shelf or terrestrial signature of basin events implies a storage time before remobilisation. Such storage may be occurring in the outershelf depocenter of the Poverty shelf, which lies upstream the Paritu Turbidite System (Fig. 2a; Orpin et al., 2006; Gerber et al., 2010).

The mechanism most likely to generate turbidity currents able to deposit such basin events is down-slope transformation of slope failures on gullied upper slopes (Middleton and Hampton, 1973; Piper et al., 1999). Since the basin events originate from the gullied upper slope, without clear shelf or terrestrial signal, we infer that the 67 basin events recognized since $\sim 18 \mathrm{ka}$ in the Paritu Turbidite System are predominantly the result of turbidity currents triggered by slope failures. The sedimentary record consequently provides a precise calendar of the 67 gullied upper-slope failures over the last $\sim 18 \mathrm{ka}$, representing an average return time of $230 \mathrm{yr}$. Amongst them, 26 events occurred during the Late Holocene (0-7 ka), 19 during the Early Holocene (7$11.6 \mathrm{ka})$, and 22 during the Late Pleistocene (11.6-18 ka).

\subsection{Earthquake control on slope failures}

Two of the major mechanisms are recognised to trigger slope failures: earthquakes (Goldfinger et al., 2007; Noda et al., 2008; St-Onge et al., 2004) and storms waves (Mulder et al., 2001; Puig et al., 2004). Tsunami waves have also been suggested, but not clearly identified (Shanmugam, 2006). The wave impact on the seafloor is commonly confined to water depths $<120-150 \mathrm{~m}$ (Lee and Edwards, 1986; Puig et al., 2004), while earthquakes may trigger slope failures at any water depth. Turbidity currents triggered by storm waves are reported as being smaller and less voluminous than those generated by earthquakes (Gorsline et al., 2000), and of lower magnitude: storm-induced gravity flows usually die out in water depths $<500 \mathrm{~m}$ and remain confined to canyon heads or gullies (Puig et al., 2004).

Our observations indicate that basin events are mostly generated on the gullied upper slope, (Figs. $6 \mathrm{~b}$ and 7), and are deposited at water depth $>1400 \mathrm{~m}$ by turbidity currents capable of reaching the 2300-m deep Lower Paritu Basin. Since the shelf edge has been located at $\sim 150 \mathrm{~m}$ since about 7 ka (Fig. 6c; Gibbs, 1986), storm waves cannot be considered as potential triggering mechanism during the Late Holocene highstand ( $0-7 \mathrm{kyr})$. However, it is quite likely that storm waves affected the paleo-shelf edge during the Early Holocene and Late Pleistocene, when sea level was lower and wind field stronger (Shulmeister et al., 2004), and added to earthquakes in slope failure generation, increasing the frequency of turbidity currents.

Considering the intense seismic activity on the Hikurangi Margin (Anderson and Webb, 1994; Doser and Webb, 2003;

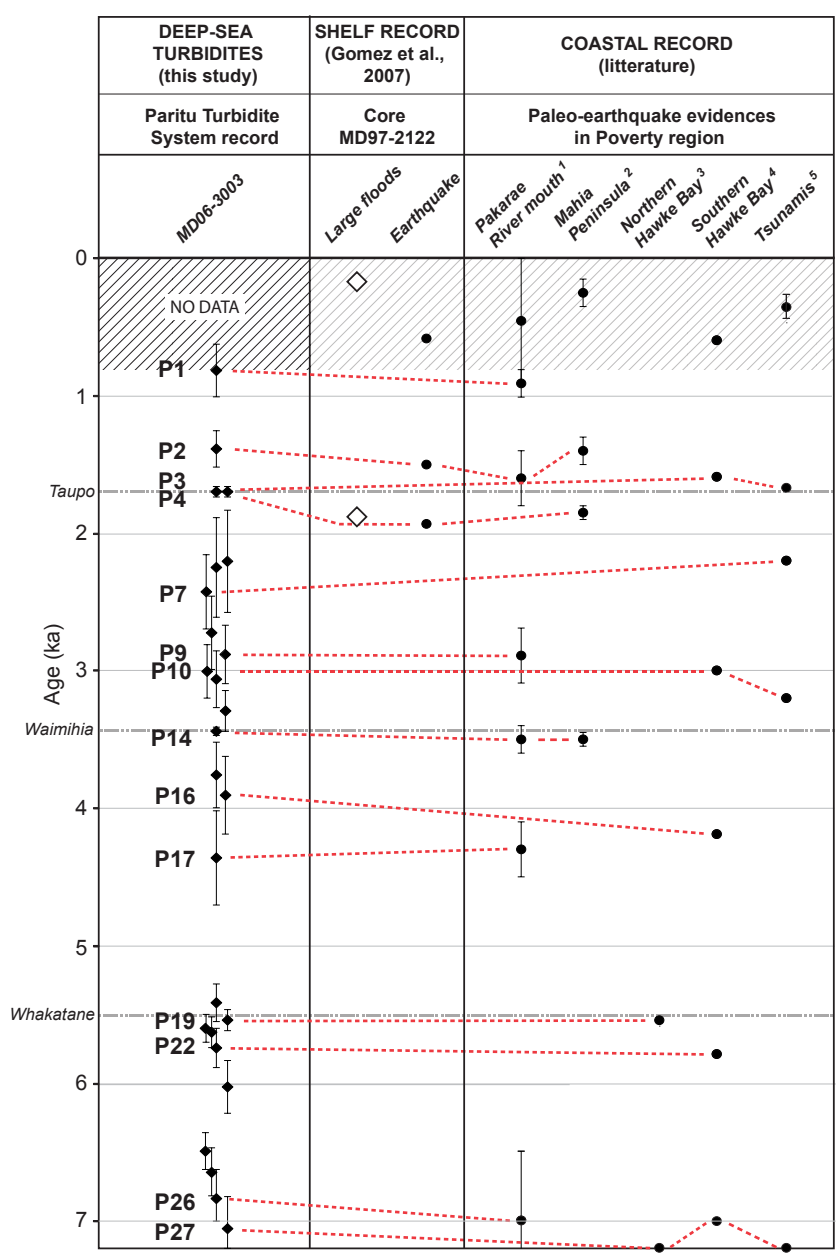

Fig. 7. Correlation (dashed red lines) between the sedimentary record of the Paritu Turbidite System and coastal paleo-earthquakes evidences since $6 \mathrm{ka}$. Large floods identified on the shelf (Gomez et al., 2007) are reported to show the non-correlation with Poverty events. Coastal record is made up of uplifted marine terraces on Pakarae River mouth (1 Wilson et al., 2007) and Mahia Peninsula (2 Berryman et al., 1993 revised by Berryman et al., 2012), sudden subsidence episodes in northern Hawke Bay (3 Cochran et al., 2006), and southern Hawke Bay (4 Hayward et al., 2006), and tsunamis deposits (5 Goff and Dominey, 2009). The names of correlative basin events are reported. Note that Poverty events not identified as slope failures deposits are not plotted (e.g. P13).

Webb and Anderson, 1998), earthquake ground-shaking is the most likely triggering mechanism for the 26 basin events identified during the Late Holocene (0-7 kyr; Table 5). This is corroborated by the temporal correlation of basin events with the paleo-earthquake data from lake, coastal and shelf records (Fig. 8; Berryman, 1993; Cochran et al., 2006; Goff and Dominey-Howes, 2009; Gomez et al., 2007; Hayward et al., 2006; Wilson et al., 2006, 2007). Coastal evidence constitutes an incomplete record of large to great earthquakes $\left(M_{\mathrm{w}}>7.5\right)$, which are generated by near-shore fault 
or plate interface ruptures (Berryman, 1993; Cochran et al., 2006; Litchfield et al., 2010). This could explain why only 14 basin events amongst the 26 identified are correlated to the coastal record. Numerous offshore faults are able to generate large earthquakes with probably no geological record onland (Fig. 1; Stirling et al., 2012), implying that the coastal record alone is not representative of the earthquake history of the Poverty re-entrant.

The 26 Late Holocene basin events are therefore interpreted as generated by earthquakes, implying that the Paritu Turbidite System can provide histories of seismic events. The return times of earthquakes since $7 \mathrm{ka}$ has oscillated between a few years to $1052 \mathrm{yr}$, with a mean return time at $250 \mathrm{yr}$ (Fig. 9a and b).

Extending these observations to the last $18 \mathrm{kyr}$, the return time of slope failures is of the same order of magnitude with similar values and trends as during the Late Holocene (Fig. 9a and c), with a mean return time at $230 \mathrm{yr}$. Similar mean return times suggest that storm waves have little impact on slope failure generation and that earthquakes have remained the most likely triggering mechanism since $18 \mathrm{ka}$. Hence, considering that the 67 basin events that occurred between $819 \pm 191$ and $17729 \pm 701 \mathrm{yr}$ BP were earthquaketriggered, we deduce a recurrence period for earthquakes of approximately $230 \mathrm{yr}$, with most occurring between 100 and $300 \mathrm{yr}$ (Fig. 9).

\subsection{Identification of local earthquake sources}

The only known active fault to have ruptured in historical times in the region is the onshore-offshore $81 \mathrm{~km}$-long Napier fault (Kelsey et al., 1998; Stirling et al., 2012). Several active faults capable of generating $M_{\mathrm{w}}>6.5$ in the Poverty Bay region have been identified onshore and offshore (Litchfield et al., 2010, Litchfield et al., 2009; Mountjoy and Barnes, 2011; Wallace et al., 2009).

Five earthquake sources are recognised offshore Poverty Bay, each associated with $M_{\mathrm{w}}>7.2$. These are the Gable End, Ariel Bank and Lachlan 3 faults, and the two HikurangiRaukumara and Hikurangi-Hawke Bay plate interface segments (Figs. 1 and 2; Table 1). These five earthquake sources are capable of generating Mercalli Modified Intensity (MMI) $\geq$ VIII on the gullied upper slope (Fig. 1; Litchfield, 2009). Such MMIs are one order of magnitude greater than the known threshold for terrestrial landsliding (MMI $\geq$ VII; Keefer, 1984; Hancox et al., 2002). Hence, we assume that these events are capable of triggering slope failures and turbidity currents in the Paritu Turbidite System. The Paritu Ridge fault was not part of the study of Litchfield et al. (2009), but has characteristics similar with Gable End and Ariel Bank faults (Table 1), which suggests that its rupture may also generate a MMI $\geq$ VIII in the gullied upper slope and trigger slope failures. Moreover, the Ariel East fault, which crosses upper-slope gully heads, can potentially generate slope failure. Consequently, these five upper plate faults, together with the two plate interface segments, are likely earthquake sources for basin events identified in the Paritu Turbidite System.

The faults earthquake return times were calculated from empirical relationships and range from 720 to $2050 \mathrm{yr}$ (Stirling et al., 2012). Other faults in the region capable of generating $M_{\mathrm{W}}=6.5$ to 7.5 are deemed too far from the source area of turbidites to trigger any recordable slope failures. In the New Zealand National Seismic Hazard Model, Stirling et al. (2012) assume that each fault ruptures independently from each other and determine the earthquake return time by summing that for each fault. Applying this simple approach to the seven active faults identified above, we estimate the number of ruptures expected for the last $18 \mathrm{kyr}$. This yields an average $M_{\mathrm{w}}=6.6$ to 8.4 earthquake return time of $\sim 130 \mathrm{yr}$ with corresponding MMI $\geq$ VIII in the gullied upper slope. This $\sim 130$-yr return time is in good agreement with the median return time of $\sim 150-160 \mathrm{yr}$ as deduced from our study (Fig. 9), suggesting that the Paritu Turbidite System provides an 18kyr history of the ruptures of the five upper plate faults and the two subduction plate interface segments. Although limitations rapidly appear in that model disregarding the characteristic of the sedimentary column on the upper slope or the impact of earthquake on the onshore landscape and river catchment, it establishes for the first time the link between earthquake-triggered turbidites and known active faults.

\subsection{Influence of repetitive earthquakes on slope stability}

The sedimentary record of the Paritu Turbidite System provides new constraints on the age of the Poverty Debris Avalanche (PDA) and its mechanism of emplacement in relation with the tectonic activity and seismic cycles. We believe that the emplacements of the PDA explain the variations in the sedimentary dynamics recognised during the two $\sim 1.2$ kyr-long intervals (Int1 and Int2).

Int2 at 13.5-14.7 ka shows a sharp switch of the main depocenter of the turbidite system from the Paritu Trough to the Lower Paritu Basin. The thickness ratio between MD063002 and MD06-3003 calculated for each basin event indicates that the Paritu Trough traps most of the sediments transported by gravity flows older than $14.7 \mathrm{ka}($ ratio $<1)$ and that the Lower Paritu Basin becomes the main depocenter from $13.5 \mathrm{ka}$ (ratio $>1$; Fig. 10a). Moreover, correlations show that, between P58 and P57, the Paritu Trough and the Lower Paritu Basin were momentarily disconnected. The reconnection (deposition of P56 and P57) was followed by strong erosion in the Paritu Trough (red line at the base of P55 in Fig. 5b). These observations suggest an abrupt transition from an unchannelized system, when turbidity currents preferentially filled the Paritu Trough, to a channelized system where currents are directed to the Lower Paritu Basin (Fig. 10b). We interpret this change as the result of the emplacement of the PDA's older unit (U2). The northern edge of the PDA created the Paritu Channel that subsequently 

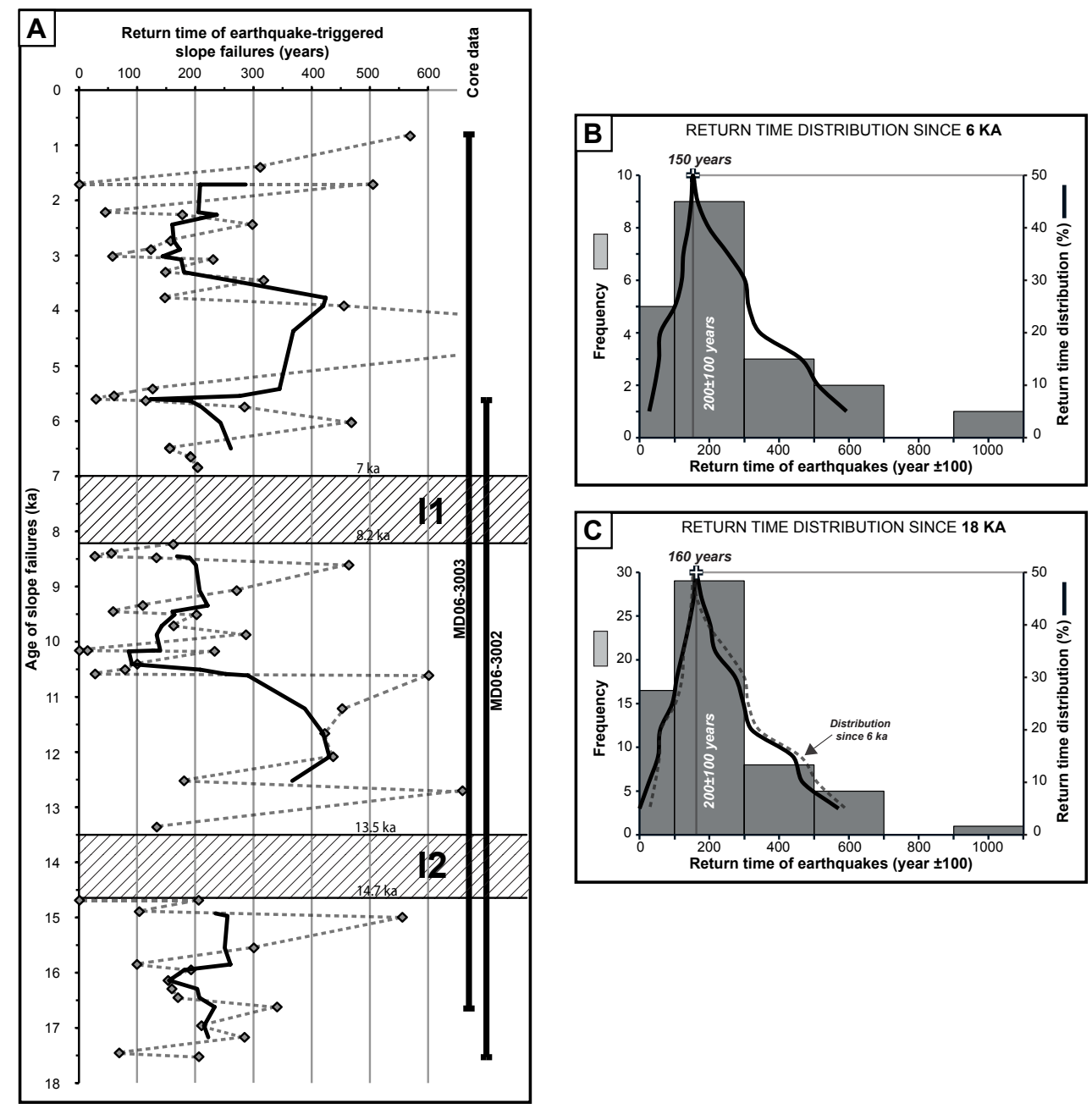

Fig. 8. (A) Return time of slope failure (i.e. basin events) trough time, over the last $18 \mathrm{kyr}$. The plot shows the age and time since the last slope failure (grey diamonds and dashed grey lines) and the running average over 5 consecutive events (black line). The time period covered by each core is mentioned on right. (B) and (C) Return time distribution of slope failure-induced basin events. The peak at 100-300 yr is constant over both the last $6 \mathrm{kyr}$ and 18 -kyr periods, suggesting that earthquakes are the primary triggering mechanisms of slope failures.

funnelled the turbidity currents to the Lower Paritu Basin, which remained the main depocenter up to $6 \mathrm{ka}$ (no data are available $<6$ ka; Fig. 10a).

During Int 1 at 7-8.2 ka, core correlations indicate a shortlived bypass of the Paritu Trough between P27-P29 (no turbidites in MD06-3003; Fig. 5a), illustrating the emplacement of the youngest unit of the PDA (U1). U1 emplaced on the upslope part of the Paritu Trough, between U2 and the gullied upper slope (Fig. 7c; Mountjoy and Micallef, 2012). Its emplacement may have temporally strengthened the channelized activity in the Paritu Trough (Fig. 10b). From 6 ka, turbidite events in the Paritu Trough were thicker and coarser than during the channelized activity of the system from 6 to $13.5 \mathrm{kyr}$ (Fig. 5), suggesting that gravity flows were no longer funnelled through the Lower Paritu Channel. The present-day morphology of the Paritu Trough and the PDA shows secondary failures and avalanches on the PDA surface (Mountjoy and Miccalef, 2012) and the partial damming of the Paritu Channel at its eastern end (Fig. 10b). The debrite identified at $\sim 5.5 \mathrm{ka}$ is probably the record of one of these secondary failures (Fig. 10a).

An overall decrease of earthquake return time from $13.5 \mathrm{ka}$ ( $\sim 400 \mathrm{yr})$ to $8.2 \mathrm{ka}(\sim 100-200 \mathrm{yr}$; Figs. 9a and 10a) is deduced from the basin events chronology. Similar decreasing trends are observed after $\mathrm{U} 1(<7 \mathrm{ka})$ and inferred before U2 $(>14.7 \mathrm{ka})$, suggesting a cyclic trend of progressive increase of earthquake frequency during periods of slope stability. The 18-kyr earthquake activity in the Poverty Bay region shows that massive slope destabilisations occurred during periods of frequent earthquakes (Fig. 10a). The increasing trend of earthquake frequency contributed to weaken the upper slope stability and favoured massive slope failures and 

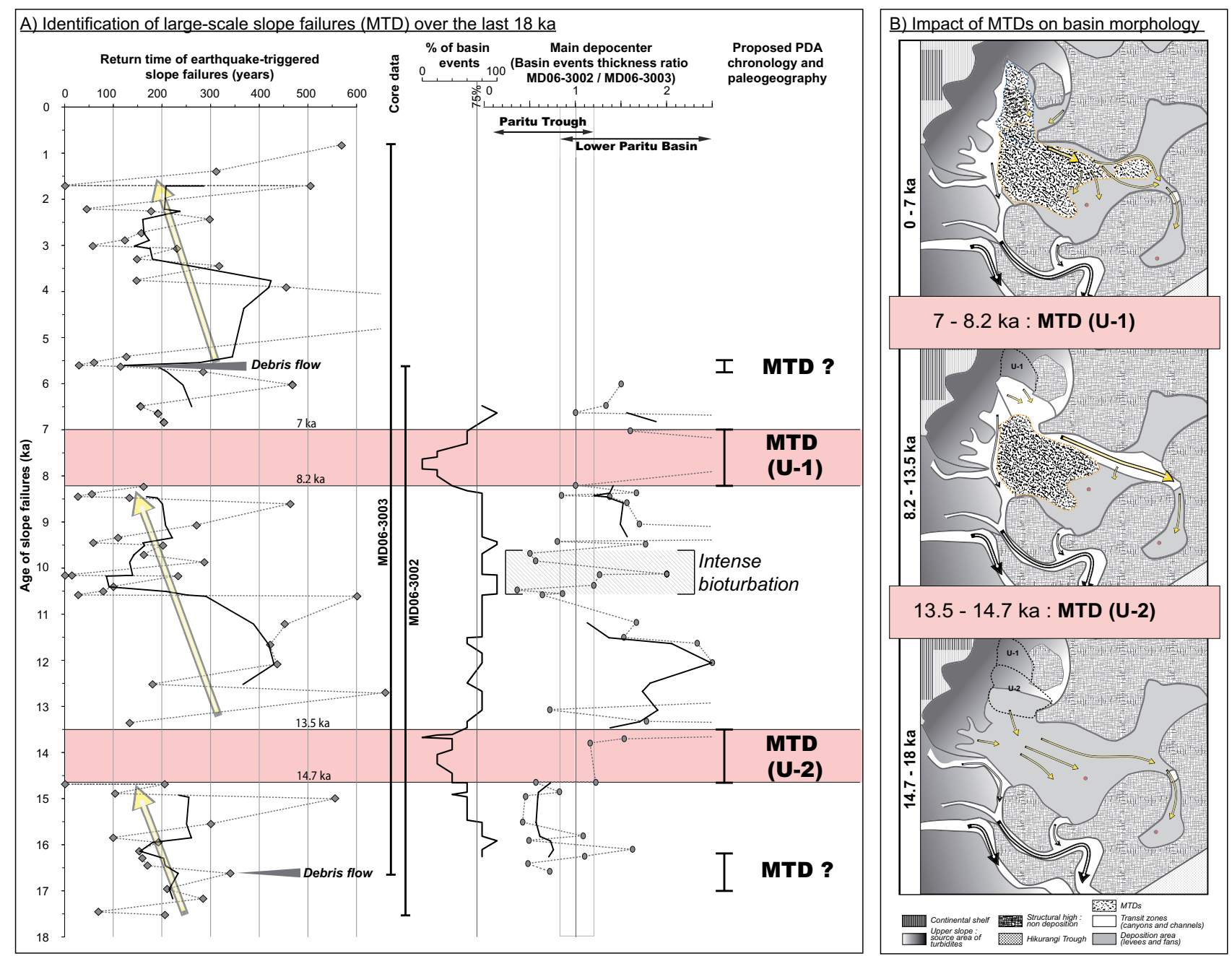

Fig. 9. (A) History of slope failures over the last $18 \mathrm{ka}$ in the Paritu mid-slope system. The two plots represent from left to right the return time of earthquake-induced slope failures trough time (from isolated and basin events), the time coverage of each sediment cores, the \% of basin events deduced from a 5-event average, the main depocenter through time deduced from the thickness ratio of basin events between the Lower Paritu Basin (MD06-3002) and the Paritu Trough (MD06-3003), and the estimated timing of the PDA. Grey dots are the data for each event whereas black lines are running average over 5 events. The latter provides the general trend (yellow arrows). Purple shade shows the two intervals (Int1 and Int2) during which we propose the occurrence of the two units of the PDA (after Mountjoy and Micallef, 2012). The $\sim 9.5-10.5$-kyr period is heavily bioturbated in cores, which may induce misinterpretation in turbidite and hemipelagite thicknesses. (B) Proposed paleo-basin morphology over the last $18 \mathrm{kyr}$, following our proposed PDA chronology and interpretation. The three maps show the three stable periods, during which gravity-flow sedimentation is regular and can be used for the turbidite paleoseismology approach. They are separated by emplacement of MTDs.

emplacement of debris avalanche. Such rationale has been suggested for the Colombian margin by Ratzov et al. (2010). Consequently, we believe that tectonic activity has a double impact on the Paritu Turbidite System: the trigger of small slope failures and turbidity currents at centennial time scales, and the trigger of massive slope failures and the control of turbidite sedimentation at millennial time scales.

\section{Conclusions}

- The 18-kyr sedimentary record of the Paritu Trough and the Lower Paritu Basin in the Poverty re-entrant is composed of $76 \%$ of centimetre-thick, turbidite events alternating with hemipelagites, tephras and debrites, at an average rate of 5.5 turbidites per meter. Turbidite events differ from other facies by their colour, grain size, internal structures, composition and geochemical signature. 
- The age of each turbidite event is calculated using the statistical approach of the OxCal software and a high resolution chronology $\left(\sim 1\right.$ age $\left.\mathrm{m}^{-1}\right)$ from radiocarbon dating of hemipelagite and tephra identification. The correlation of turbidite events between cores (based on facies, petrophysical properties, and ages) allowed the identification of 73 basin events (correlative turbidite events) emplaced since $18 \mathrm{ka}$.

- The morphology of the Paritu System, the foraminiferal content and the geochemical signature of the turbidites indicate that 67 basin events were deposited by single gravity flows sourced from slope failures on the gullied upper slope. 26 basin events occurred during the Late Holocene (0-7 ka), and the remaining 41 basin events occurred during the Early Holocene and Late Pleistocene $(7-18 \mathrm{ka})$.

- Earthquakes are the most likely triggering mechanism of slope failures and the 26 basin events during the Late Holocene. These indicate a mean return time of earthquakes of $250 \mathrm{yr}$. The 67 basin events since $18 \mathrm{ka}$ exhibit a comparable mean return time of $230 \mathrm{yr}$, suggesting earthquakes have remained the most likely triggering mechanisms since $18 \mathrm{ka}$.

- The estimated $\sim 130 \mathrm{yr}$ earthquake return time along seven offshore active faults, including the two plate interface segments, is close to the $\sim 160 \mathrm{yr}$ median return time of earthquakes deduced from basin events. These faults can generate MMI > VIII scale ground motion on the gullied upper slope, which is believed to generate slope failures and basin events.

- The history of earthquakes, deduced from the basin events chronology, suggests a cyclic trend of progressive increase of earthquake frequency from $\sim 400 \mathrm{yr}$ to $\sim 100-200 \mathrm{yr}$ on average, during the period $8.2-$ $13.5 \mathrm{kyr}$, as well as during the $0-7$ and $14.7-18-\mathrm{kyr}$ periods. The two $1.2 \mathrm{kyr}-$ long intervals at $7-8.2 \mathrm{ka}$ and 13.5-14.7 ka are interpreted as basin-wide reorganisations of sediment pathways following high seismic activity and emplacement of mass flow deposits in the Paritu Trough.

\section{Supplementary material related to this article is available online at: \\ http://www.nat-hazards-earth-syst-sci.net/12/2077/2012/ nhess-12-2077-2012-supplement.pdf.}

Acknowledgements. This project was funded by the Centre National de la Recherche Scientifique - Institut National des Sciences de l'Univers (CNRS-INSU Research Program "Aléas, risques et catastrophes telluriques") and the New Zealand Ministry of Science and Innovation (previously Foundation for Research Science and
Technology) through their programme Paleoseismicity of the Alpine Fault and Hikurangi Margin (C01X0801). This study is part of a PhD undertaken at the University of Rennes 1 (Géosciences Rennes) and NIWA, funded by a research grant from Ministère de l'Enseignement Supérieur et de la Recherche. The French Ministry of Foreign Affairs (French Embassy in Wellington) and the Université Européenne de Bretagne provided support funds for international travel. Gary Wilson facilitated access to the University of Otago's Geotek Multi-Track Sensor. Philip Barnes, Alan Orpin and Helen Neil (NIWA) contributed through numerous constructive discussions. Marie-Pierre Dabard (Geosciences Rennes, University of Rennes 1) helped with foraminifers and sand composition analysis. Alan Orpin (NIWA) provided the grain-size data of MD06-3003. Helen Neil (NIWA) performed the organic carbon analysis and stable isotope analyses of sediments, assisted by Julie Brown and Sarah Bury. Thanks go to Hans Nelson, Lionel Carter, Chris Goldfinger and Cecilia McHugh for their constructive reviews.

Edited by: H. Nelson

Reviewed by: L. Carter and C. M. McHugh

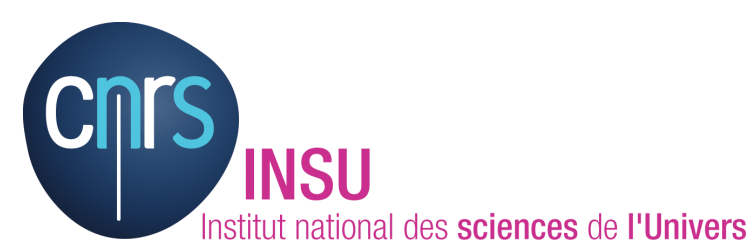

The publication of this article is financed by CNRS-INSU.

\section{References}

Adams, J.: Paleoseismicity of the Cascadia subduction zone: Evidence from turbidites off the Oregon-Washington margin, Tectonics, 9, 569-583, 1990.

Alexander, C. R., Walsh, J. P., and Orpin, A. R.: Modern sediment dispersal and accumulation on the outer Poverty continental margin, Mar. Geol., 270, 213-226, 2010.

Anderson, H. and Webb, T.: New Zealand seismicity: patterns revealed by the upgraded National Seismograph Network, NZ. J. Geol. Geophys., 37, 477-493, 1994.

Berryman, K.: Age, height, and deformation of Holocene marine terraces at Mahia Peninsula, Hikurangi subduction margin, New Zealand, Tectonics, 12, 1347-1364, 1993.

Beavan, J., Tregoning, P., Bevis, M., Kato, T., and Meertens, C.: Motion and rigidity of the Pacific Plate and implications for plate boundary deformation, J. Geophys. Res., 107, 2261, doi:10.1029/2001JB000282, 2002.

Bouma, A. H.: Sedimentology of some flysh deposits, A graphic approach to facies interpretation, Elsevier, 168 pp., 1962.

Brackley, H. L., Blair, N. E., Trustrum, N. A., Carter, L., Leithold, E. L., Canuel, E. A., Johnston, J. H., and Tate, K. R.: Dispersal and transformation of organic carbon across an episodic, high sediment discharge continental margin, Waipaoa Sedimentary System, New Zealand, Mar. Geol., 270, 202-212, 2010.

Bronk-Ramsey, C.: Deposition models for chronological records, Quaternary Sci. Rev., 27, 42-60, 2008. 
Canals, M., Puig, P., Durrieu de Madron, X., Heussner, S., Palanques, A., and Fabres, J.: Flushing submarine canyons, Nature, 444, 354-357, doi:10.1038/nature05271, 2006.

Carter, L., Nelson, C. S., Neil, H. L., and Froggatt, P. C.: Correlation, dispersal, and presentation of the Kawakawa tephra and other Late Quaternary tephra layers in the southwest Pacific Ocean, NZ J. Geol. Geophys., 38, 29-46, 1995.

Carter, L., Manighetti, B., Ganssen, G., and Northcote, L.: Southwest Pacific modulation of abrupt climate change during the Antarctic Cold Reversal - Younger Dryas, Palaeogeogr. PPalaeocl., 260, 284-298, 2008.

Cochran, U., Berryman, K., Zachariasen, J., Mildenhall, D., Hayward, B., Southall, K., Hollis, C., Barker, P., Wallace, L., Alloway, B., and Wilson, K.: Paleoecological insights into subduction zone earthquake occurrence, eastern North Island, New Zealand, Geol. Soc. Am. Bull., 118, 1051-1074, 2006.

Collot, J. Y., Lewis, K., Lamarche, G., and Lallemand, S.: The giant Ruatoria debris avalanche on the northern Hikurangi margin, New Zealand: Result of oblique seamount subduction, J. Geophys. Res.-Sol. Ea., 106, 19271-19297, 2001.

Doser, D. I. and Webb, T. H.: Source parameters of large historical (1917-1961) earthquakes, North Island, New Zealand, Geophys. J. Int., 152, 795-832, 2003.

Downes, G., Webb, T., McSaveney, M., Darby, D., Doser, D., Chagué-Goff, C., and Barnett, A.: The March 25 and May 171947 Gisborne earthquakes and tsnunamis: implication for tsunami hazard for East Coast, North Island, New Zealand, Tsunami Risk Assessment Beyond 2000, Moscow Tsunami Workshop 2000, 2000.

Foster, G. and Carter, L.: Mud sedimentation on the continental shelf at an accretionary margin - Poverty Bay, New Zealand, NZ J. Geol. Geophys., 40, 157-173, 1997.

Gerber, T. P., Pratson, L. F., Kuehl, S., Walsh, J. P., Alexander, C., and Palmer, A.: The influence of sea level and tectonics on Late Pleistocene through Holocene sediment storage along the high-sediment supply Waipaoa continental shelf, Mar. Geol., 270, 139-159, 2010.

Gibb, J.: A New Zealand regional Holocene eustatic sea-level curve and its application to determination of vertical tectonic movements, Roy. Soc. NZ Bull., 24, 377-395, 1986.

Goff, J. and Dominey-Howes, D.: Australasian paleotsunamis - Do Australia and New Zealand have a shared trans-Tasman prehistory?, Earth-Sci. Rev., 97, 147-154, 2009.

Goldfinger, C., Nelson, C. H., Johnson, J. E., and Shipboard Sci., P.: Deep-water turbidites as Holocene earthquake proxies: the Cascadia subduction zone and Northern San Andreas Fault systems, Ann. Geophys., 46, 1169-1194, 2003,

http://www.ann-geophys.net/46/1169/2003/.

Goldfinger, C., Grijalva, K., Burgmann, R., Morey, A. E., Johnson, J. E., Nelson, C. H., Gutierrez-Pastor, J., Ericsson, A., Karabanov, E., Chaytor, J. D., Patton, J., and Gràcia, E.: Late Holocene rupture of the northern San Andreas Fault and possible stress linkage to the Cascadia subduction zone, Bull. Seism. Soc. Am., 98, 861-889, 2008.

Goldfinger, C., Morey, A. E., Nelson, C. H., Gutierrz-Pastor, J., Johnson, J. E., Karabanov, E., Chaytor, J., Eriksson, A., and Shipboard Scientific Party: Rutpure lengths and temporal history of significant earthquakes on the offshore and north coast segments of the northern San Andreas Fault based on turbidite stratigraphy,
Earth Planet. Sci. Lett., 254, 9-27, 2007.

Gomez, B., Carter, L., Trustrum, N. A., Palmer, A. S., and Roberts, A. P.: El Nino-Southern Oscillation signal associated with middle Holocene climate change in intercorrelated terrestrial and marine sediment cores, North Island, New Zealand, Geology, 32, 653656, 2004.

Gomez, B., Carter, L., and Trustrum, N. A.: A 2400 yr record of natural events and anthropogenic impacts in intercorrelated terrestrial and marine sediment cores: Waipaoa sedimentary system, New Zealand, Geol. Soc. Am. Bull., 119, 1415-1432, 2007.

Gorsline, D. S., De Diego, T., and Nava-Sanchez, E. H.: Seismically triggered turbidites in small basins: Alfonso Basin, Western Gulf of California and Santa Monica Basin, California Borderland, Sedim. Geol., 135, 21-35, 2000.

Gràcia, E., Vizcaino, A., Escutia, C., Asioli, A., Rodes, A., Pallas, R., Garcia-Orellana, J., Lebreiro, S., and Goldfinger, C.: Holocene earthquake record offshore Portugal (SW Iberia): testing turbidite paleoseismology in a slow-convergent margin, Quaternary Sci. Rev., 29, 1156-1172, 2010.

Hancox, G. T., Perrin, N. D., and Dellow, G. D.: Recent studies of historical earthquake-induced landsliding, ground damage, and MM intensity in New Zealand. Bull. NZ Soc. Earthq. Eng., 35, 59-95, 2002.

Haughton, P., Davis, C., McCaffrey, W., and Barker, S.: Hybrid sediment gravity flow deposits - Classifcation, origin and significance, Mar. Petrol. Geol., 26, 1900-1918, 2009.

Hayward, B. W., Grenfell, H. R., Sabaa, A. T., Carter, R., Cochran, U., Lipps, J. H., Shane, P. R., and Morley, M. S.: Micropaleontological evidence of large earthquakes in the past 7200 years in southern Hawke's Bay, New Zealand, Quaternary Sci. Rev., 25, 1186-1207, 2006.

Hicks, D. M. and Shankar, U.: Sediment yield from New Zealand rivers, NIWA chart, Miscellaneous series N.79, National Institute of Water and Atmospheric Research, Wellington, New Zealand, 2003.

Hicks, D. M., Gomez, B., and Trustrum, N. A.: Event suspended sediment characteristics and the generation of hyperpycnal plumes at river mouths: East Coast Continental Margin, North Island, New Zealand, J. Geol., 112, 471-485, 2004.

Huh, C. A., Su, C. C., Liang, W. T., and Ling, C. Y.: Linkages between turbidites in the southern Okinawa Trough and submarine earthquakes, Geophys. Res. Lett., 31, L12304, doi:10/1029/2004GL019731, 2004.

Keefer, D. K.: Statistical analysis of an earthquake-induced landslide distribution - the 1989 Loma Prieta, California event, Eng. Geol., 58, 231-249, 2000.

Keefer, D. K., Wartman, J., Ochoa, C. N., Rodriguez-Marek, A., and Wieczorek, G. F.: Landslides caused by the M 7.6 Tecoman, Mexico earthquake of January 21, 2003, Eng. Geol., 86, 183197, 2006.

Kelsey, H. M., Hull, A. G., Cashman, S. M., Berryman, K. R., Cashman, P. H., Trexler, J. H., and Begg, J. G.: Paleoseismology of an active reverse fault in a forearc setting: the Poukawa fault zone, Hikurangi forearc, New Zealand, Geol. Soc. Am. Bull., 110, 1123-1148, 1998.

Kettner, A. J., Gomez, B., and Syvitski, J. P. M.: Modeling suspended sediment discharge from the Waipaoa River system, New Zealand: The last 3000 years, Wat. Resour. Res., 43, W07411, doi:10.1029/2006WR005570, 2007. 
Lee, H. J. and Edwards, B. D.: Regional assess offshore slope stability, J. Geotech. Eng.-ASCE, 112, 489-509, 1986.

Lewis, K. B. and Pettinga, J. R.: The merging, imbricate frontal wedge of the Hikurangi margin, in: South Pacific Sedimentary Basins, Sedimentary Basins of the World, Vol. 2, edited by: Balance, P. F., Elsevier Science Publishers, Amsterdam, 225-250, 1993.

Lewis, K. B., Lallemand, S. E., and Carter, L.: Collapse in a Quaternary shelf basin off East Cape, New Zealand: evidence for passage of a subducted seamount inboard of the Ruatoria giant avalanche, NZ J. Geol. Geophys., 47, 415-429, 2004.

Litchfield, N. J., Berryman, K. R., and Smith, W. D.: Return times for high levels of ground shaking (MM7) in the Waipaoa and Waitaki River catchments, GNS Science Report 2009/03, 94 pp., 2009.

Litchfield, N., Wilson, K., Berryman, K., and Wallace, L.: Coastal uplift mechanisms at Pakarae River mouth: Constraints from a combined Holocene fluvial and marine terrace dataset, Mar. Geol., 270, 72-83, 2010.

Lowe, D. J., Shane, P. A. R., Alloway, B. V., and Newnham, R. M.: Fingerprints and age models for widespread New Zealand tephra marker beds erupted since 30,000 years ago: a framework for NZ-INTIMATE, Quaternary Sci. Rev., 27, 95-126, 2008.

Manville, V. and Wilson, C. J. N.: Vertical density currents: a review of their potential role in the deposition and interpretation of deepsea ash layers, J. Geol. Soc., London, 161, 947-958, 2004.

McGlone, M. S. and Wilmshurst, J. M.: Dating initial Maori environmental impacts in New Zealand, Quatern. Int., 59, 5-16, 1999.

McGlone, M. S., Anderson, A. J., and Holdaway, R. N.: An ecological approach to the Polynesian settlement of New Zealand, in: The Origins of the First New Zealanders, edited by: Sutton, D. G., Auckland University Press, 136-163, 1994.

McHugh, C. M. G., Seeber, L., Cormier, M-H., Dutton, J., Cagatay, N., Polonia, A., Ryan, W. B. F., and Gorur, N.: Submarine earthquake geology along the North Anatolia Fault in the Marmara Sea, Turkey: A model for transform basin sedimentation, Earth Planet. Sci. Lett., 248, 661-684, 2006.

McHugh, C. M. G., Seeber, L., Braudy, N., Cormier, M. H., Davis, M. B., Diebold, J. B., Dieudonne, N., Douilly, R., Gulick, S. P. S., Hornbach, M. J., Johnson III, H. E., Ryan Miskin, K., Sorlien, C. C., Steckler, M. S., Symithe, S. J., and Templeton, J.: Offshore sedimentary effects of the 12 January 2010 Haiti earthquake, Geology, 39, 723-726, 2011.

Middleton, G. V. and Hampton, M. A.: Sediment gravity flows: mechanics of flow and deposition. In: Turbidity and Deep Water Sedimentation, edited by: Middleton, G. V. and Bouma, A. H., SEPM, 1-38, 1973.

Miller, A. J. and Kuelh, S. A.: Shelf sedimentation on a tectonically active margin: A modern sediment budget for Poverty continental shelf, New Zealand, Mar. Geol., 270, 175-187, 2010.

Mountjoy, J. J. and Barnes, P. M.: Active upper plate thrust faulting in regions of low plate interface coupling, repeated slow slip events, and coastal uplift: example from the Hikurangi Margin, New Zealand, Geochem. Geophys. Geosyst., 12, Q01005, doi:10.1029/2010GC003326, 2011.

Mountjoy, J. J. and Micallef, A.: Polyphase emplacement of a $30 \mathrm{~km}^{3}$ blocky debris avalanche and its role in slopegully development, in: Submarine Mass Movements and Their
Consequences, Adv. Nat. Tech. Hazards Res., 31, 213-222, doi:10.1007/978-94-007-2162-3_19, 2012.

Mulder, T., Weber, O., Anschutz, P., Jorissen, F. J., and Jouanneau, J. M.: A few months-old storm-generated turbidite deposited in the Capbreton Canyon (Bay of Biscay, SW France), Geo-Mar. Lett., 21, 149-156, 2001.

Mulder, T., Syvitski, J. P. M., Migeon, S., Faugeres, J. C., and Savoye, B.: Marine hyperpycnal flows: initiation, behavior and related deposits, A review, Mar. Petrol. Geol., 20, 861-882, 2003.

Nakajima, T. and Kanai, Y.: Sedimentary features of seismoturbidites triggered by the 1983 and older historical earthquakes in the eastern margin of the Japan Sea, Sediment. Geol., 135, 1-19, 2000.

Noda, A., TuZino, T., Kanai, Y., Furukawa, R., and Uchida, J. I.: Paleoseismicity along the southern Kuril Trench deduced from submarine-fan turbidites, Mar. Geol., 254, 73-90, 2008.

Orpin, A. R.: Holocene sediment deposition on the Poverty-slope margin by the muddy Waipaoa River, East Coast New Zealand, Mar. Geol., 209, 69-90, 2004.

Orpin, A. R., Alexander, C., Carter, L., Kuehl, S., and Walsh, J. P.: Temporal and spatial complexity in post-glacial sedimentation on the tectonically active, Poverty Bay continental margin of New Zealand, Contin. Shelf Res., 26, 2205-2224, 2006.

Pantosti, D., Gràcia, E., and Nelson, C. H.: Searching for records of past earthquakes under water, EOS Trans. Am. Geophys. Union, 92, 8 February 2011, p. 48, doi:10.1029/2011EO060005, 2011.

Pedley, K. L., Barnes, P. M., Pettinga, J. R., and Lewis, K. B.: Seafloor structural geomorphic evolution of the accretionary frontal wedge in response to seamount subduction, Poverty Indentation, New Zealand, Mar. Geol., 270, 119-138, 2010.

Piper, D. J. W. and Normark, W. R.: Processes that initiate turbidity currents and their influence on turbidites: a marine geology perspective, J. Sediment. Res., 79, 347-362, 2009.

Piper, D. J. W., Cochonat, P., and Morrison, M. L.: The sequence of events around the epicentre of the 1929 Grand Banks earthquake: initiation of debris flows and turbidity current inferred from sidescan sonar, Sedimentology, 46, 79-97, 1999.

Pouderoux, H., Proust, J. N., Lamarche, G., Orpin, A., and Neil, H.: Deep-sea sedimentation along the Hikurangi subduction margin (New Zealand) since the Last Glacial Maximum: characterisation, timing and origin of turbidites, Mar. Geol., 295-298, 51-76, 2012.

Puig, P., Ogston, A. S., Mullenbach, B. L., Nittrouer, C. A., Parsons, J. D., and Sternberg, R. W.: Storm-induced sediment gravity flows at the head of the Eel submarine canyon, northern California margin, J. Geophys. Res.-Ocean., 109, C03019, doi:10/1029/2003JC001918, 2004.

Proust, J. N., Lamarche, G., Migeon, S., and Neil, H. L.: Climate and tectonic changes in the océan around New Zealand, EOS Transaction American Geophysical Union, 89, 277-288, 2008.

Ratzov, G., Collot, J. Y., Sosson, M., and Migeon, S.: Masstransport deposits in the northern Ecuador subduction trench: result of frontal érosion over multiple seismic cycles, Earth Planet. Sci. Lett., 296, 89-102, 2010.

Reyners, M.: Plate coupling and the hazard of large subduction thrust earthquakes at the Hikurangi subduction zone, New Zealand, NZ J. Geol. Geophys., 41, 343-354, 1998.

Reyners, M. and McGinty, P.: Shallow subduction tectonics in the Raukumara peninsula, New Zealand, as illuminated by earth- 
quake focal mechanisms, J. Geophys. Res.-Sol. Earth, 104, 3025-3034, 1999.

Rose, L. E. and Kuehl, S. A.: Recent sedimentation patterns and facies distribution on the Poverty Shelf, New Zealand, Mar. Geol., 270, 160-174, 2010.

Schnellmann, M., Anselmetti, F. S., Giardini D., McKenzie, J. A., and Ward, S. N.: Prehistoric earthquake history revealed by lacustrine slump deposits, Geology, 30, 1131-1134, 2002.

Shane, P.: Tephrochronology: a New Zealand case study, Earth Sci. Rev., 49, 223-259, 2000.

Shanmugam, G.: The Tsunamite problem, J. Sediment. Res., 76, 718-730, 2006.

Shulmeister, J., Goodwin, I., Renwick, J., Harle, K., Armand, L., McGlone, M. S., Cook, E., Dodson, J., Hesse, P. P., Mayewski, P., and Curran, M.: The Southern Hemisphere westerlies in the Australasian sector over the last glacial cycle: a synthesis, Quatern. Int., 118-119, 23-53, 2004.

Sikes, E. L., Samson, C. R., Guilderson, T. P., and Howard, W. R.: Old radiocarbon ages in the southwest Pacific Ocean during the last glacial period and deglaciation, Nature, 405, 555-559, 2000.

St-Onge, G., Mulder, T., Piper, D. J. W., Hillaire-Marcel, C., and Stoner, J. S.: Earthquake and flood-induced turbidites in the Saguenay Fjord (Quebec): a Holocene paleoseismicity record, Quaternary Sci. Rev., 23, 283-294, 2004.

Stirling, M., McVerry, G., Gerstenberger, M., Litchfield, N., Van Dissen, R., Berryman, K., Barnes, P., Wallace, L., Bradley, B., Villamor, P., Langrodge, R., Lamarche, G., Nodder, S., Reyners, M., Rhodades, D., Smith, W., Nicol, A., Pettinga, J., Clark, K., and Jacobs, K.: National Seismic Hazard Model for New Zealand: 2010 Update, Bull. Seism. Soc. Am., in press, 2012.

Stow, D. A. V. and Shanmugam, G.: Sequence of structures in finegrained turbidites - Comparison of recent deep-sea and ancient flysch sediments, Sediment. Geol., 25, 23-42, 1980.

Strasser, M., Stegmann, S., Bussmann, F., Anselmetti, F. S., Rick, B., and Kopf, A.: Quantifying subaqueous slope stability during seismic shaking: Lake Lucerne as model for ocean margins, Mar. Geol., 240, 77-97, 2007.
Wallace, L. M., Reyners, M., Cochran, U., Bannister, S., Barnes, P. M., Berryman, K., Downes, G., Eberhart-Phillips, D., Fagereng, A., Ellis, S., Nicol, A., McCaffrey, R., Beavan, R. J., Henrys, S., Sutherland, R., Barker, D. H. N., Litchfield, N., Townend, J., Robinson, R., Bell, R., Wilson, K., and Power, W.: Characterizing the seismogenic zone of a major plate boundary subduction thrust: Hikurangi Margin, New Zealand, Geochem. Geophys. Geosyst., 10, Q100006, doi:10.1029/2009GC002610, 2009.

Walsh, J. P., Alexander, C. R., Gerber, T., Orpin, A. R., and Sumners, B. W.: Demise of a submarine canyon? Evidence for highstand infilling on the Waipaoa Rievr continental margin, New Zealand, Geophys. Res. Lett., 34, L20606, doi:10.1029/2007GL031142, 2007.

Webb, T. H. and Anderson, H.: Focal mechanisms of large earthquakes in the North Island of New Zealand: slip partitioning at an oblique active margin, Geophys. J. Int., 134, 40-86, 1998.

Wiesner, M. G., Wang, Y., and Zheng, L.: Fallout of volcanic ash to the deep South China Sea induced by the 1991 eruption of Mount Pinatubo (Philippines), Geology, 23, 885-888, 1995.

Wilson, C. J. N.: Stratigraphy, chronology, styles and dynamics of late Quaternary eruptions from Taupo volcano, New Zealand, Philo. Trans. Royal Soc., London, 343, 205-306, 1993.

Wilson, K., Berryman, K., Litchfield, N., and Little, T.: A revision of mid-late Holocene marine terrace distribution and chronology at the Pakarae River mouth, North Island, New Zealand, NZ J. Geol. Geophys., 49, 477-489, 2006.

Wilson, K., Berryman, K., Cochran, U., and Little, T.: Early Holocene paleoseismic history at the Pakarae locality, eastern North Island, New Zealand, inferred from transgressive marine sequence architecture, Tectonics, 26, TC4013, doi:10.1029/2006TC002021, 2007.

Wright, L. D. and Friedrichs, C. T.: Gravity-driven sediment transport on continental shelves: a status report, Contin. Shelf Res., 26, 2092-2107, 2006. 